\title{
O gênero Myrcia (Myrtaceae) nos campos rupestres de Minas Gerais, Brasil ${ }^{1}$
}

\author{
The genus Myrcia (Myrtaceae) in "campos rupestres" of Minas Gerais, Brazil
}

\author{
Priscila Oliveira $\operatorname{Rosa}^{2,3}$ \& Rosana Romero ${ }^{2}$
}

\begin{abstract}
Resumo
Myrtaceae é reconhecidamente uma família de grande importância no bioma Cerrado. Dentre os gêneros da família, Myrcia desponta como um dos mais representativos e com centros de distribuição geográfica nos estados de Minas Gerais e Goiás. O presente estudo revela a ocorrência de 33 espécies de Myrcia nos campos rupestres e fisionomias florestais associadas de Minas Gerais. O presente tratamento para o gênero no estado apresenta chave de identificação, descrições, dados de distribuição geográfica e comentários sobre as espécies. Palavras-chave: Cadeia do Espinhaço, Complexo Serra da Canastra, diversidade de Myrcia, Minas Gerais, Myrtaceae, tratamento taxonômico.
\end{abstract}

\begin{abstract}
Myrtaceae is admittedly a family of great importance in the Cerrado biome. Myrcia is one of the most representative genera of the family, with the main distribution centers in the states of Minas Gerais and Goiás. The current study reveals the occurrence of 33 Myrcia species in the "campos rupestres" and associated forest formations of Minas Gerais. Treatment of the genus includes identification keys, descriptions, geographic distribution data and comments on the species.
\end{abstract}

Key words: Espinhaço Chain, Serra da Canastra Complex, Myrcia diversity, Minas Gerais, Myrtaceae, taxonomic treatment.

\section{Introdução}

Myrtaceae é uma família com cerca de 130 gêneros e aproximadamente 5.700 espécies (Govaerts et al. 2008), com centros de diversidade na Austrália, sudeste da Ásia, América do Sul tropical e temperada (Wilson et al. 2001). No Brasil, a família apresenta 927 espécies distribuídas em 24 gêneros (Sobral et al. 2010), estando bem representada nas diferentes fitofisionomias do bioma Cerrado, principalmente nos campos rupestres, onde figura entre as 10 famílias de maior riqueza (Werneck et al. 2000; Zappi et al. 2003; Hatschbach et al. 2006; Neri et al. 2007; Viana \& Lombardi 2007; Alves \& Kolbek 2009; Ferreira \& Forzza 2009).

O gênero Myrcia DC. ex Guill., com 374 espécies (Govaerts et al. 2008), ocorre desde a América Central até o norte da Argentina (Landrum \& Kawasaki 1997). No Brasil são encontradas 214 espécies e os estados de Minas Gerais e Goiás são considerados os principais centros de distribuição (Berg 1857-1859; Legrand 1968).

Estudos realizados com as Myrtaceae nos campos rupestres da Serra do Cipó (Kawasaki 1989), Ouro Preto (Peron 1994), Serra do Caraça (Morais \& Lombardi 2006) e Serra do Cabral (Hatschbach et al. 2006), em Minas Gerais, mostram que Myrcia é o gênero mais representativo em número de espécies.

A composição florística dos campos rupestres vem sendo investigada ao longo dos últimos 30 anos anos (Harley \& Simmons 1986; Giulietti et al. 1987; Meguro et al. 1994; Pirani et al. 1994; Stannard 1995; Guedes \& Orge 1998; Munhoz \& Proença 1998; Nakajima \& Semir 2001; Romero \& Martins 2002; Pirani et al. 2003; Conceição \& Pirani 2007; Conceição et al. 2007; Mourão \& Stehmann 2007; Viana \& Lombardi 2007) e os estudos demonstram a grande diversidade e o alto índice de endemismo dessa fitofisionomia (Harley 1995).

\footnotetext{
${ }^{1}$ Parte da Dissertação de Mestrado da primeira autora, defendida no Programa de Pós-Graduação em Ecologia e Conservação de Recursos Naturais da Universidade Federal de Uberlândia.

${ }^{2}$ Universidade Federal de Uberlândia, Instituto de Biologia, 38.400-902, Uberlândia, Minas Gerais, Brasil

${ }^{3}$ Autora para correspondência: priscilaoliveirarosa@yahoo.com.br
} 
O presente estudo tem como objetivo apresentar as espécies de Myrcia que ocorrem nos campos rupestres de Minas Gerais.

\section{Material e Métodos}

Área de estudo

O campo rupestre, uma fitofisionomia do bioma Cerrado (sensu Ribeiro \& Walter 2008), apresenta como principais características a predominância do estrato herbáceo-arbustivo com arvoretas esparsas, e ocorre associado a afloramentos rochosos em altitudes geralmente superiores a 900 metros com grandes variações de temperatura no período de um dia (Ribeiro \& Walter 2008). Tais áreas apresentam solos rasos, pobres em nutrientes e com baixa capacidade de retenção de água (Ribeiro \& Walter 2008). Condições ecológicas distintas, e o consequente isolamento geográfico, propiciaram o desenvolvimento de uma flora conspícua, marcada pela presença de espécies raras e endêmicas (Giulietti \& Pirani 1988, Giulietti \& Forero 1990; Harley 1995; Romero \& Nakajima 1999; Conceição \& Pirani 2007).

No presente estudo foram analisadas espécies de Myrcia que ocorrem nos campos rupestres e nas fisionomias circundantes a esse, como os capões de mata e suas bordas. Em Minas Gerais, o campo rupestre distribui-se ao longo da Cadeia do Espinhaço, um grande maciço, que se estende da Serra de Ouro Branco até o Planalto de Diamantina, onde apresenta disjunções, como as serras do Cabral e de Grão Mogol, nas áreas a sudoeste do estado, no Complexo da Serra da Canastra e ao sul, nas serras de Carrancas, de Tiradentes e do Ibitipoca (Giulietti et al. 2000; Romero 2002; Vitta 2002).

\section{Levantamento das espécies}

No presente estudo foram analisados cerca de 2.500 espécimes de Myrcia depositados nos herbários BHCB, HUFU, MBM, OUPR, RB, SP, SPF e UEC (siglas de acordo com Thiers 2010), que contam com importantes coleções dos campos rupestres de Minas Gerais.

Algumas espécies de Gomidesia O. Berg e Marlierea Cambess., recentemente incluídas como sinônimos de Myrcia, também foram analisadas. A classificação adotada no presente estudo segue Govaerts et al. (2008) e Sobral et al. (2010).

Entre os anos de 2007 e 2008 foram realizadas coletas nos campos rupestres das Serras de Ouro Branco, Ouro Preto, Lavras Novas, Biribiri, Milho Verde, Conselheiro Mata, Diamantina, Mendanha, Joaquim Felício, Buenópolis, Cristália, Grão Mogol e Botumirim. Todo material coletado encontra-se depositado no Herbarium Uberlandense (HUFU), da Universidade Federal de Uberlândia, Minas Gerais. Devido ao volume de exsicatas examinadas, foi relacionado apenas um material representativo de cada espécie. A relação completa do material examinado está disponível com a primeira autora.

A identificação dos espécimes de Myrcia, com ocorrência nos campos rupestres de Minas Gerais, foi realizada com base na literatura (De Candolle 1828; Berg 1857-1859; Legrand \& Klein 1967, 1969; Kawasaki 1989; Nic Lughadha 1995; Arantes \& Monteiro 2002; Morais \& Lombardi 2006) e nas fotografias dos tipos.

As descrições morfológicas das estruturas vegetativas e reprodutivas foram realizadas com base no material examinado, adotando-se a terminologia de Radford (1986). A descrição de M. uberavensis O.Berg foi complementada com base em exemplares coletados em campo rupestre do estado de São Paulo (Sasaki \& Mello-Silva 2008).

As chaves de identificação para as espécies de Myrcia foram elaboradas com base nos caracteres analisados para a confecção das descrições. A chave I abrange as espécies com indumento persistente, enquanto a chave II remete para as espécies com pouco ou nenhum indumento.

\section{Resultados e Discussão}

Myrcia DC. ex Guill.

Árvores ou arbustos. Folhas geralmente opostas, mais raramente alternas ou verticiladas. Panículas multifloras, paucifloras, raramente racemos, dicásios ou flores solitárias axilares; brácteas e bractéolas geralmente caducas; cálice aberto, ocasionalmente fechado no botão floral, 5-mero, raramente 4-mero, sépalas distintas; hipanto prolongado ou não acima do ovário; pétalas geralmente 5 ; estames numerosos, anteras poricidas ou rimosas; ovário 2-3(4)-locular, 2 óvulos axilares por lóculo. Baga coroada pelos remanescentes do cálice ou prolongamento do hipanto; sementes com testa membranácea ou cartilaginosa, embrião mircióide.

O gênero Myrcia está representado nos campos rupestres de Minas Gerais por 33 espécies, com algumas destas ocorrendo, geralmente, nas bordas de mata, fisionomia comumente inserida na paisagem típica de campo rupestre (Pirani et al. 2003).

Das espécies analisadas, apenas Myrcia dealbata DC., M. nivea Cambess. e M. pinifolia Cambess. ocorrem exclusivamente em campo rupestre, sendo M. dealbata DC. a única restrita aos 
campos rupestres mineiros. Myrcia subcordata DC. e M. vauthiereana O.Berg, apesar de restritas ao estado de Minas Gerais, também são encontradas em outras fitofisionomias, como nos campos de altitude da Serra do Caparaó. Outras espécies apresentam distribuição mais ampla, ocorrendo em diferentes biomas brasileiros, além do Cerrado, como, por exemplo, M. amazonica DC., M. guianensis (Aubl.) DC., M. laruotteana Cambess., M. multiflora (Lam.) DC., M. splendens (Sw.) DC. e M. tomentosa (Aubl.) DC.. As demais espécies de Myrcia ocorrem em campo rupestre e nas fisionomias associadas, como florestas de encosta e florestas que acompanham o curso de pequenos rios ou campos hidromórficos.

\section{Chaves de identificação para as espécies de Myrcia dos campos rupestres de Minas Gerais Chave I: Ramos com indumento persistente}

1. Hipanto não prolongado acima do ovário.

2. Folhas cartáceas, indumento dourado glabrescente nas folhas e persistente na ráquis 10. M. lasiantha

2'. Folhas membranáceas, indumento ferrugíneo na margem foliar ciliada, hirsuto e persistente nos ramos

5. M. eriopus

1'. Hipanto prolongado acima do ovário.

3. Ramos e ráquis com indumento ocráceo ou ferrugíneo.

4. Sépalas glabras em ambas as faces.

5. Folhas congestas no ápice dos ramos, cálice 4-mero

20. M. pulchra

5' Folhas não congestas no ápice dos ramos, cálice 5-mero

23. M. rufipes

4'. Sépalas com indumento interno, externo ou em ambas as faces.

6. Indumento ocráceo ou ocráceo a nigrescente.

7. Ramos cilídricos, pecíolo 4-6 mm compr.; lâmina foliar 0,5-7 × 0,3-2,5 cm ......

32. M. venulosa

7'. Ramos quadrangulares, pecíolo 10-20 mm compr.; lâmina foliar 1-17×3,5-5,5 cm

6'. Indumento ferrugíneo.

15. M. nobilis

8. Gema apical não protegida por catafilos, folhas alternas na base, opostas no ápice

27. M. subverticillaris

8'. Gema apical protegida por catafilos, folhas opostas 13. M. mutabilis

3'. Ramos e ráquis com indumento cinéreo, creme, dourado ou pardacento a nigescente.

9. Indumento creme, dourado ou pardacento a nigrescente.

10. Ramos quadrangulares ou subquadrangulares.

11. Ramos jovens e ráquis com indumento creme a nigrescente

2. M. anceps

11'. Ráquis e ramos jovens com indumento pardacento a nigrescente

11. M. mischophylla

10’. Ramos cilíndricos.

12. Nervuras proeminentes na face abaxial da lâmina foliar.

13. Árvore 4-5 m alt., folhas com margem convoluta

6. M. fenzliana

13'. Subarbustos ou árvores $0,4-2 \mathrm{~m}$ alt., folhas com margem revoluta

4. M. eriocalyx

12'. Nervuras não proeminentes na face abaxial da lâmina foliar.

14. Filotaxia outra que não essencialmente oposta.

15. Folhas opostas cruzadas, panículas compostas do tipo tirsóide

29. M. uberavensis

15'. Folhas alternas, raro verticiladas, panículas essencialmente terminais...

33. M. vestita

14'. Filotaxia oposta.

16. Subarbustos, ramos achatados, indumento creme, folhas concolores ....

7. M. guianensis 
16'. Arbustos ou árvores, ramos cilíndricos, indumento pardacento, folhas discolores 22. M. retorta

9'. Indumento cinéreo.

17. Flores pediceladas.

18. Flores solitárias 1-3 por axila, pétalas róseas

14. M. nivea

18'. Dicásios, pétalas alvas

17'. Flores sésseis

28. M. tomentosa

\section{Chave II: Ramos glabros ou glabrescentes, indumento sempre esparso quando presente}

1. Hipanto não prolongado acima do ovário.

2. Panículas, brácteas e bractéolas caducas

24. M. splendens

2'. Racemos, brácteas e bractéolas persistentes 31. M. vauthiereana

1'. Hipanto prolongado acima do ovário.

3. Plantas glabrescentes.

4. Folhas esverdeadas mesmo após herborizadas.

5. Folhas discolores, nervuras amarronzadas em material herborizado, flores pediceladas 12. M. multiflora

5'. Folhas concolores, nervuras não amarronzadas em material herborizado, flores sésseis 9. M. laruotteana

4'. Folhas amarronzadas após herborizadas.

6. Hipanto glabro.

7. Folhas sésseis

26. M. subcordata

7'. Folhas pecioladas

19. M. pubiflora

6'. Hipanto piloso.

8. Flores aglomeradas no ápice da inflorescência

18. M. pubescens

8'. Flores não aglomeradas no ápice da inflorescência

1. M. amazonica

3'. Plantas glabras ou com indumento apenas na face externa das sépalas.

9. Folhas sésseis ou subsésseis com pecíolo até $2 \mathrm{~mm}$ compr.

10. Folhas cordadas a oblonga ou ovada

11. Subarbusto xilopodífero, folhas verticiladas na base do ramo, opostas no ápice ..

11'. Árvores, folhas opostas cruzadas em todo o ramo 3. M. dealbata

10'. Folhas lanceoladas ou lineares.

12. Panícula 30. M. variabilis

12'. Racemo

17. M. pinifolia

21. M. racemulosa

9'. Folhas pecioladas de 3-7 $\mathrm{mm}$ compr.

13. Panículas.

14. Ramos nodosos, folhas concolores

8. M. hartwegiana

14'. Ramos não nodosos, folhas discolores 16. M. obovata

13'. Cimeira 7. M. guianensis

1. Myrcia amazonica DC., Prodromus 3: 250. 1828.

Fig. 1a

Arbustos ou árvores, 2-6 m alt. Ramos não nodosos, cilíndricos, descamantes, foliáceos, indumento cinéreo, nos mais jovens ferrugíneo, glabrescente, gema apical não recoberta por catafilos. Folhas opostas, discolores, não congestas no ápice dos ramos, pecíolo canaliculado, 4-9 mm compr.; lâmina 1,5-10 × 0,5-3 cm, cartácea, marrom escura depois de herborizada, lanceolada, ápice acuminado, margem não revoluta, base aguda, indumento ferrugíneo concentrado na nervura principal da face adaxial, face abaxial glabra, com pontuações alvas, esparsas, indumento em ambas as faces quando jovens. Panículas multifloras, axilares ou subterminais, flores não aglomeradas no ápice da inflorescência; botões florais 1,5-2 × 1-1,5 mm, obovados, pilosos; brácteas e bractéolas caducas, cálice aberto no botão, 5-mero, sépalas $0,5-1 \mathrm{~mm}$ compr., ápice 
arredondado a obtuso, interna e externamente com indumento, margem ciliada; hipanto prolongado acima do ovário, externamente piloso. Baga imatura ca. $2 \times 2 \mathrm{~mm}$, globosa, glabrescente.

Material selecionado: São Roque de Minas, Parque Nacional da Serra da Canastra, Cachoeira Casca D'Anta, 19.X.1994, J.N. Nakajima et al. 595 (HUFU).

Segundo Govaerts et al. (2008), esta espécie apresenta distribuição por toda a América Tropical, ocorrendo comumente em floresta de galeria, cerrado, campo rupestre (Peron 1994), floresta semidecidual e capoeira (Morais \& Lombardi 2006).

Myrcia amazonica se distingue das demais pelas folhas lanceoladas, de coloração marrom escura depois de herborizada, com indumento ferrugíneo pouco denso em ambas as faces e pontuações alvas, esparsas, na face abaxial da lâmina.

2. Myrcia anceps (Spreng.) O. Berg., in Mart., Eichler \& Urban, Flora brasiliensis 14(1): 186. 1857.

Fig. 1b

Árvores, 2-3 m alt. Ramos não nodosos, subquadrangulares, achatados, não descamantes, indumento creme, persistente na ráquis e nos ramos jovens, gema apical não recoberta por catafilos. Folhas opostas, discolores, não congestas no ápice dos ramos, pecíolo canaliculado, 3-9 mm compr.; lâmina 3,5-12 × 1-5 cm, coriácea, oblongolanceolada ou lanceolada, ápice acuminado, margem não revoluta, base obtusa, face adaxial glabra, com pontuações translúcidas, face abaxial com indumento creme a nigrescente, nervuras proeminentes. Panículas multifloras, axilares ou subterminais, flores não aglomeradas no ápice da inflorescência; botões florais 2-4 × 1-3 mm, globosos, pilosos; brácteas e bractéolas caducas, pétalas alvas; cálice aberto no botão, 5-mero, sépalas 1-1,5 mm compr., ápice agudo a arredondado, interna e externamente com indumento cinéreo, margem ciliada; hipanto prolongado acima do ovário, externamente piloso. Baga madura 2-3× 2-3 mm, globosa, pilosa.

Material selecionado: Ouro Branco, Serra de Ouro Branco, 16.X.2007, J.N. Nakajima et al. 4580 (HUFU).

Myrcia anceps é encontrada em borda de floresta associada aos campos rupestres das Serras de Ouro Branco e Ouro Preto, sendo este o primeiro registro para os campos rupestres de Minas Gerais. Segundo Sobral et al. (2010), esta espécie ocorre no Sudeste do Brasil, nos estados de São Paulo,
Espírito Santo, Rio de Janeiro e Minas Gerais, associada a formações florestais e na transição entre formações campestres.

Myrcia anceps chama a atenção pela floração massiva, sendo prontamente reconhecida por seus ramos subquadrangulares, achatados, botões florais grandes $(2-4 \times 1-3 \mathrm{~mm})$ quando comparado às demais espécies, e nervuras proeminentes na face abaxial da lâmina foliar.

\section{Myrcia dealbata DC., Prodromus 3: 254. 1828. \\ Fig. 1c}

Subarbustos xilopodíferos, ca. $0,5 \mathrm{~m}$ alt. Ramos não nodosos, cilíndricos, não descamantes, glabros, gema apical não recoberta por catafilos. Folhas verticiladas na base do ramo, opostas no ápice, concolores, não congestas no ápice dos ramos, sésseis; lâmina $0,5-5 \times 0,5-3 \mathrm{~cm}$, coriácea, marrom escura depois de herborizada, cordada a ovada, ápice agudo, margem levemente revoluta, base cordada, face adaxial com nervura proeminente, ambas as faces glabras, face abaxial das folhas jovens com pontuações translúcidas. Panículas multifloras, axilares ou terminais, flores não aglomeradas no ápice da inflorescência; botões florais 3-4 × 2-4 mm, claviformes, glabros; brácteas e bractéolas caducas; pétalas alvas; cálice aberto no botão, 5-mero, sépalas 0,5-1 mm compr., ápice agudo a obtuso, interna e externamente glabras, margem ciliada; hipanto prolongado acima do ovário, externamente glabro. Frutos não vistos. Material selecionado: Engenho Bilia-Gouveia, 13.IX.1985, G. Hatschbach \& R. Kummrow 49621 (MBM).

Myrcia dealbata é restrita ao estado de Minas Gerais (Sobral et al. 2010) e, juntamente com $M$. subavenia são as únicas que apresentam xilopódio. Myrcia dealbata é prontamente reconhecida pelas folhas coriáceas, sésseis, verticiladas apenas na base dos ramos e panículas multifloras.

4. Myrcia eriocalyx DC., Prodromus 3: 255. 1828.

Fig. 1d

Subarbustos ou árvores, 0,4-2 m alt. Ramos não nodosos, cilíndricos, não descamantes, com indumento dourado, posteriormente nigrescente, persistente, gema apical não recoberta por catafilos. Folhas opostas, concolores, não congestas no ápice dos ramos, pecíolo canaliculado, até $6 \mathrm{~mm}$ compr.; lâmina 1-8 × 0,5-3,5 cm, coriácea, ovada ou cordada, ápice agudo a acuminado, margem revoluta, base cuneada, face adaxial glabrescente, 

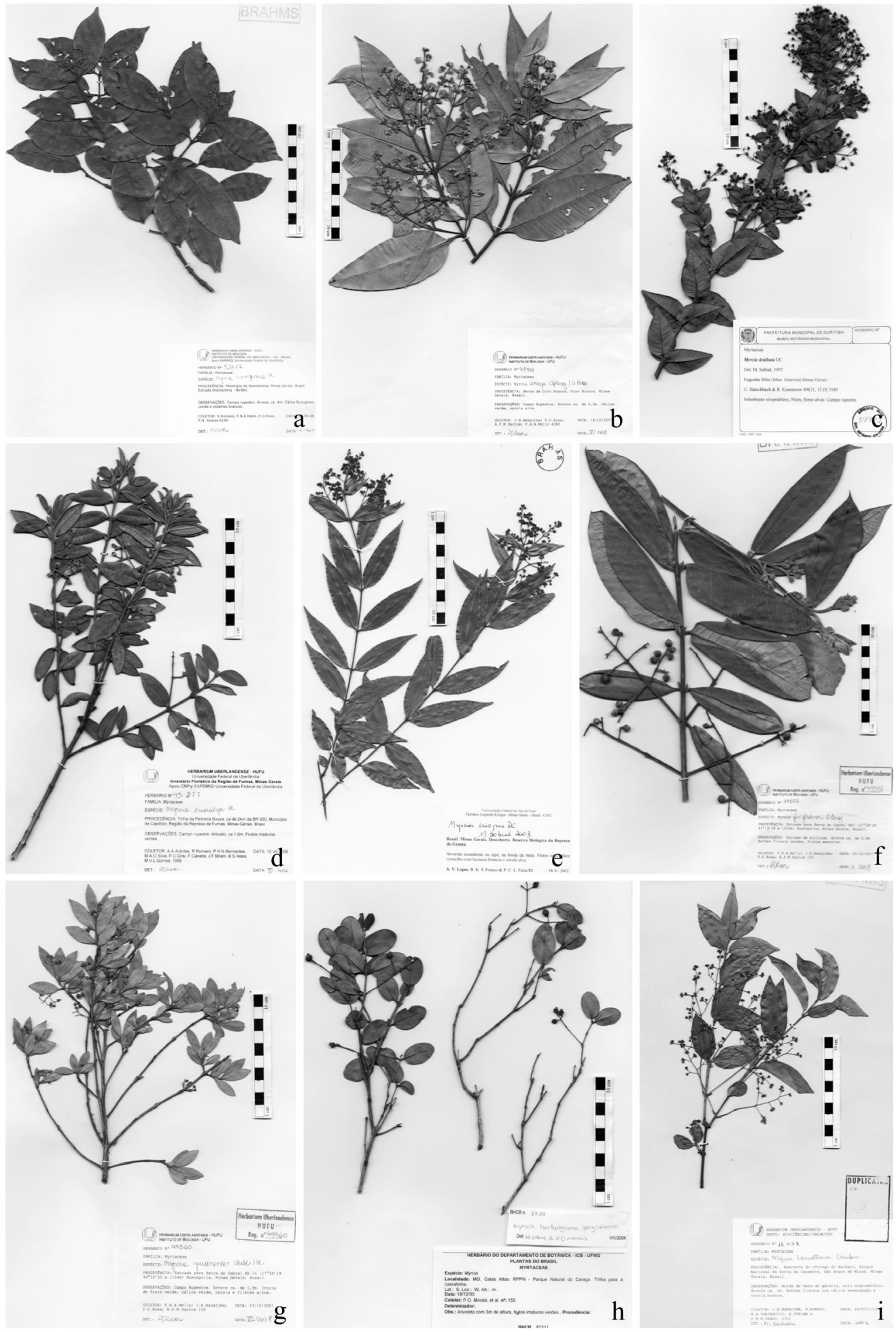

Figura 1 - a. Myrcia amazonica DC.; b. M. anceps (Spreng.) O. Berg.; c. M. dealbata DC.; d. M. eriocalyx DC.; e. M. eriopus DC.; f. M. fenzliana O. Berg; g. M. guianensis (Aubl.) DC.; h. M. hartwegiana (O. Berg) Kiaersk.; i. M. laruotteana Cambess.

Figure 1 - a. Myrcia amazonica DC.; b. M. anceps (Spreng.) O. Berg.; c. M. dealbata DC.; d. M. eriocalyx DC.; e. M. eriopus DC.; f. M. fenzliana O. Berg; g. M. guianensis (Aubl.) DC.; h. M. hartwegiana (O. Berg) Kiaersk.; i. M. laruotteana Cambess. 
face abaxial com indumento persistente, nervuras proeminentes, pontuações translúcidas em ambas as faces. Panículas paucifloras, axilares ou subterminais, flores não aglomeradas no ápice da inflorescência; botões florais 3-4 × ca. $4 \mathrm{~mm}$, globosos, pilosos; brácteas e bractéolas caducas; pétalas alvas; cálice aberto no botão, 5-mero, sépalas 2-3 mm compr., ápice agudo, interna e externamente com indumento denso, margem glabra; hipanto prolongado acima do ovário, externamente piloso. Baga madura 1,5-7 ×2-7 mm, globosa, imatura glabrescente, madura vinácea. Material selecionado: Delfinópolis, Condomínio de Pedras, 28.XI.2003, R. Romero et al. 7009 (HUFU).

Segundo Govaerts et al. (2008), M. eriocalyx ocorre no Sudeste e Centro-Oeste do Brasil, enquanto Sobral et al. (2010) apontam sua ocorrência apenas para os estados de Minas Gerais, Espírito Santo e Bahia. Dados de herbário mostram a ocorrência desta espécie também para o Rio de Janeiro. No estado de Minas Gerais é frequentemente encontrada também em Cerrado, próximo a floresta ciliar (Kawasaki 1989), floresta semidecidual, afloramento rochoso e capoeira (Morais \& Lombardi 2006).

Myrcia eriocalyx e M. lasiantha são espécies próximas, que se diferenciam por $M$. eriocalyx apresentar folhas coriáceas, maiores $(1-8 \times 0,5-3,5$ $\mathrm{cm}$ ), indumento dourado a nigrescente e hipanto prolongado acima do ovário. Já $M$. lasiantha apresenta folhas cartáceas, menores $(0,5-2,5 \times$ $0,5-1,5 \mathrm{~cm})$, indumento dourado e hipanto não prolongado acima do ovário.

\section{Myrcia eriopus DC., Prodromus 3: 255. 1828.}

Fig. 1e

Arbustos escandentes. Ramos não nodosos, cilíndricos, não descamantes, indumento hirsuto, ferrugíneo, persistente nos ramos, gema apical não recoberta por catafilos. Folhas opostas, concolores, não congestas no ápice dos ramos, pecíolo canaliculado, 1-2 mm compr.; lâmina $1-7,5 \times 0,5-2 \mathrm{~cm}$, membranácea, lanceolada, ápice acuminado, margem ciliada, ondulada depois de seca, base atenuada a obtusa, ambas as faces glabrescentes, face adaxial com pontuações translúcidas. Panículas paucifloras, axilares ou subterminais, flores não aglomeradas no ápice da inflorescência; botões florais 1,5-3 × 1-2,5 $\mathrm{mm}$, globosos, pilosos; brácteas e bractéolas persistentes; pétalas alvas; cálice aberto no botão, 5-mero, sépalas até $0,5 \mathrm{~mm}$ compr., ápice arredondado, interna e externamente glabras, margem ciliada; hipanto não prolongado acima do ovário. Frutos não vistos.

Material selecionado: Ouro Preto, Parque Estadual do Itacolomi, 18.XI.1987, M. Peron 489 (SP).

Segundo Govaerts et al. (2008), M. eriopus ocorre no Sudeste e Centro-Oeste brasileiro, podendo ser encontrada em sub-bosque de floresta atlântica e, de galeria, campo rupestre, Cerrado (Peron 1994) e floresta ciliar (Kawasaki 1989).

Myrcia eriopus é uma das quatro espécies encontradas nos campos rupestres de Minas Gerais que não formam hipanto e apresenta como característica mais marcante o indumento hirsuto ferrugíneo que recobre os ramos.

6. Myrcia fenzliana $\mathrm{O}$. Berg, in Mart., Eichler \& Urban, Flora brasiliensis 14(1): 196. 1857.

Fig. $1 \mathrm{f}$

Árvores, 4-5 m alt. Ramos não nodosos, cilíndricos, não descamantes, indumento pardacento, persistente, gema apical não recoberta por catafilos. Folhas opostas, discolores, não congestas no ápice dos ramos, pecíolo canaliculado, 3-8 mm compr.; lâmina 2-14 × 1-7 cm, coriácea, ovada a oblonga, ápice acuminado, margem convoluta, base obtusa, face adaxial com pontuações translúcidas, tomentosa nas folhas jovens, face abaxial com indumento denso, pardacento, nervura proeminente. Panículas paucifloras, axilares, flores não aglomeradas no ápice da inflorescência; botão floral não visto; brácteas e bractéolas caducas; pétalas alvas; cálice aberto no botão, 5-mero, sépalas até $0,3 \mathrm{~mm}$ compr., ápice agudo, interna e externamente com indumento, margem ciliada; hipanto prolongado acima do ovário, externamente piloso. Baga madura 3-7 × 3-8 mm, globosa, pilosa, alaranjada.

Material selecionado: Joaquim Felício, Serra do Cabral, 22.X.2007. A.P.M. Santos et al. 497 (HUFU).

Segundo Govaerts et al. (2008), esta espécie distribui-se do Caribe até o Brasil, ocorrendo em campos rupestres das serras de São João del Rei, Diamantina e Serra do Cabral.

Myrcia fenzliana é prontamente reconhecida pelo porte arbóreo, folhas com margem convoluta e indumento denso, pardacento na face abaxial da lâmina.

7. Myrcia guianensis (Aubl.) DC., Prodromus 3: 245. 1828 . Fig. $1 \mathrm{~g}$

Subarbustos, arbustos ou árvores, até $4 \mathrm{~m}$ alt. Ramos nodosos ou não, cilíndricos ou achatados, descamantes ou não, glabros ou com indumento 
creme e persistente quando presente, gema apical não recoberta por catafilos. Folhas opostas, concolores, sésseis ou pecíolo canaliculado até $4 \mathrm{~mm}$ compr.; lâmina $0,5-6 \times 0,2-3 \mathrm{~cm}$, membranácea a coriácea, linear, elíptica a obovada ou ovada a cordada, ápice agudo, obtuso ou arredondado, margem levemente revoluta ou não, base atenuada a aguda, indumento creme quando presente, geralmente concentrado na ráquis, na face adaxial das folhas maduras e em ambas as faces das folhas jovens, pontuações translúcidas nos indivíduos glabros. Panículas multifloras ou cimeiras, axilares, subterminais ou terminais, flores não aglomeradas no ápice da inflorescência; botões florais 1-6 × 1-5 mm, globosos ou obovados, pilosos ou glabros; brácteas e bractéolas caducas; pétalas alvas ou róseas; cálice aberto no botão, 5-mero, sépalas 0,5-3 mm compr., ápice agudo, acuminado, obtuso ou arredondado, internamente com indumento, externamente glabra, margem ciliada; hipanto prolongado acima do ovário, externamente glabro. Baga madura 2-8 $\times$ 1-7 mm, globosa, glabra, glândulas visíveis.

Material selecionado: Capitólio, Serra de Furnas-Paraíso Perdido, 29.IX.2005, R. Romero et al. 7233 (HUFU).

Myrcia guianensis é amplamente distribuída desde Trinidad e Tobago até o Brasil, com ocorrência em todo o território brasileiro (Govaerts et al. 2008). Esta espécie é comumente encontrada em floresta ciliar (Kawasaki 1989), fenda de afloramento quartzítico, formações secundárias (Peron 1994), Cerrado, campo cerrado e campo sujo (Arantes \& Monteiro 2002).

Das espécies de Myrcia que ocorrem nos campos rupestres de Minas Gerais, M. guianensis é a que apresenta maior variação morfológica, ocupando os estratos subarbustivo, arbustivo e arbóreo.

\section{Myrcia hartwegiana (O. Berg) Kiaersk.,} Enumeratio Myrtacearum Brasiliensium 109. 1893.

Fig. $1 \mathrm{~h}$

Arvoretas ou árvores, 1,5-3 m alt. Ramos nodosos, cilíndricos, descamantes, foliáceos, glabros, gema apical não recoberta por catafilos. Folhas opostas, concolores, não congestas no ápice dos ramos, pecíolo canaliculado, 3-4 mm compr.; lâmina 1-3,5 × 0,5-2 cm, coriácea, marrom depois de herborizada, elíptica a oblonga, ápice arredondado, margem revoluta, base cuneada, ambas as faces glabras, pontuações nigrescentes. Panículas paucifloras, axilares ou subterminais, flores não aglomeradas no ápice da inflorescência; botões florais 3-4 × 1,5-2 mm, globosos, pilosos; brácteas e bractéolas caducas; pétalas alvas; cálice aberto no botão, 5-mero, sépalas $0,5-1$ $\mathrm{mm}$ compr., ápice agudo, internamente glabras, externamente com indumento, margem ciliada; hipanto prolongado acima do ovário, externamente piloso. Baga madura 3,5-5 × 3-6 mm, globosa, glabra, verrucosa.

Material selecionado: Diamantina, estrada para Milho Verde, $1 \mathrm{~km}$ após São Gonçalo do Rio das Pedras, 19.V.2008, J.N. Nakajima et al. 4911 (HUFU).

Segundo Govaerts et al. (2008), esta espécie distribui-se no Sudeste e Sul do Brasil, ocorrendo em campo rupestre, floresta ciliar e capoeira (Morais \& Lombardi 2006).

Myrcia hartwegiana diferencia-se das demais por apresentar ramos nodosos e folhas com margem revoluta e ambas as faces glabras.

9. Myrcia laruotteana Cambess., Flora Brasiliae Meridionalis 2: 311. 1832. Fig. 1i

Arvoretas ou árvores, 3-4 m alt. Ramos não nodosos, achatados no ápice, descamantes, indumento cinéreo, pontuações visíveis por todo ramo, glabrescente, gema apical não recoberta por catafilos. Folhas opostas, concolores, não congestas no ápice dos ramos, pecíolo canaliculado, 2-6 mm compr.; lâmina 1,5-5,5 ×0,5-2,5 cm, membranácea, elíptica a obovada, ápice arredondado a acuminado, margem ondulada depois de seca, base cuneada a truncada, ambas as faces glabrescentes, indumento cinéreo, esparso na face abaxial das folhas jovens. Panículas multifloras, axilares ou terminais, flores não aglomeradas no ápice da inflorescência, sésseis; botões florais 1-3 × 1,5-3 mm, globosos, glabros; brácteas e bractéolas caducas; pétalas alvas; cálice aberto no botão, 5-mero, sépalas 0,5-1 mm compr., ápice arredondado, interna e externamente glabras, margem ciliada; hipanto prolongado acima do ovário, externamente glabro. Baga madura 2-3× 1-3 mm, globosa, glabra, amarelada.

Material selecionado: Serra da Moeda, 12.IX.1998, J.A. Lombardi 2394 (SPF).

Espécie com ocorrência na Argentina, Paraguai e Brasil (Govaerts et al. 2008), em floresta ciliar, capão de mata (Kawasaki 1989; Peron 1994), borda de floresta de galeria (Arantes \& Monteiro 2002), campo rupestre (Peron 1994) e campo (Morais \& Lombardi 2006).

Myrcia laruotteana é próxima de $M$. multiflora, da qual se diferencia pelos ramos achatados no ápice, margem foliar ondulada depois de herborizada e flores sésseis. 
10. Myrcia lasiantha DC., Prodromus 3: 254. 1828.

Fig. 2a

Subarbustos ou arbustos, até $1 \mathrm{~m}$ alt. Ramos nodosos, cilíndricos, não descamantes, indumento dourado nas folhas jovens, viloso, glabrescente, persistente na ráquis, gema apical não recoberta por catafilos. Folhas opostas cruzadas, concolores, não congestas no ápice dos ramos, sésseis; lâmina $0,5-2,5 \times 0,5-1,5 \mathrm{~cm}$, cartácea, ovada a cordada, ápice agudo a obtuso, margem levemente revoluta, base cordada, ambas as faces das folhas jovens com indumento, folhas maduras glabrescentes, nervuras proeminentes na face abaxial. Panículas paucifloras, axilares ou terminais, flores não aglomeradas no ápice da inflorescência; botões florais $2-4 \times$ ca. $2 \mathrm{~mm}$, globosos, pilosos; brácteas e bractéolas caducas; pétalas alvas; cálice aberto no botão, 5-mero, sépalas 1-1,5 mm compr., ápice agudo, interna e externamente com indumento; margem ciliada; hipanto não prolongado acima do ovário. Baga madura $2-5 \times 1,5-4,5 \mathrm{~mm}$, globosa a elipsóide, glabrescente, verrucoso-glandulosa, alaranjada a nigrescente.

Material selecionado: Belo Horizonte-Conceição do Mato Dentro, Serra do Cipó, 5.XII.1981, N. Hensold et al. 7714 (SPF).

Myrcia lasiantha distribui-se no Sudeste e Centro-Oeste brasileiro (Sobral et al. 2010), e além do campo rupestre, também ocorre em campo cerrado (Kawasaki 1989).

As semelhanças com a espécie mais próxima, $M$. eriocalyx, já foram discutidas nos comentários desta.

11. Myrcia mischophylla Kiaersk., Enumeratio Myrtacearum Brasiliensium 61. 1893. Fig. 2b Arvoretas ou árvores, 4-5,5 $\mathrm{m}$ alt. Ramos não nodosos, quadrangulares, achatados, não descamantes, indumento pardacento a nigrescente, persistente na ráquis, gema apical não recoberta por catafilos. Folhas opostas, discolores, não congestas no ápice dos ramos, pecíolo canaliculado, 7-15 mm compr.; lâmina 5-12,5 × 1-4,5 cm, coriácea, elíptica a lanceolada, ápice longo-acuminado, margem levemente revoluta, base obtusa, face adaxial glabra, indumento esparso apenas na nervura central, pontuações nigrescentes, face abaxial com indumento pardacento a alaranjado, pontuações cinéreas. Panículas multifloras, axilares ou terminais, flores não aglomeradas no ápice da inflorescência; botões florais 2-3,5 × 2,5-3 mm, globosos, pilosos; brácteas e bractéolas caducas; pétalas alvas; cálice aberto no botão, 5-mero, sépalas $0,5-1 \mathrm{~mm}$ compr., ápice obtuso, interna e externamente com indumento, margem ciliada; hipanto prolongado acima do ovário, externamente piloso. Baga madura 3-5 × 3,5-6 mm, globosa, glabrescente, amarelada.

Material selecionado: Buenópolis, Serra do Cabral, 23.X.2007, F.N.A. Mello et al. 147 (HUFU).

Myrcia mischophylla distribui-se nos estados de Minas Gerais e Bahia (Sobral et al. 2010), ocorrendo também em floresta ciliar (Kawasaki 1989).

Apesar da semelhança com Myrcia nobilis, por ambas apresentarem pecíolos longos e folhas grandes, M. mischophylla diferencia-se pelo indumento mais claro, folhas menores, com margem não ondulada e ápice longamente acuminado.

12. Myrcia multiflora (Lam.) DC., Prodromus 3: 244. 1828. Fig. 2c

Árvores, 2-3 m alt. Ramos não nodosos, cilíndricos, descamantes, indumento cinéreo, glabrescentes, ramos jovens com indumento, gema apical não recoberta por catafilos. Folhas opostas, discolores, não congestas no ápice dos ramos, pecíolo canaliculado, 1-4 mm compr.; lâmina 0,5-6 $\times 0,4-2 \mathrm{~cm}$, membranácea, lanceolada a elíptica, ápice agudo a acuminado, margem não revoluta, base atenuada, ambas as faces glabrescentes, nervuras nigrescentes na face adaxial, pontuações translúcidas. Panículas multifloras, axilares ou terminais, flores não aglomeradas no ápice da inflorescência; botões florais 1,5-3 × 1-3 mm, obovados, glabros; brácteas e bractéolas caducas; pétalas alvas; cálice aberto no botão, 5-mero, sépalas até $0,5 \mathrm{~mm}$ compr., ápice arredondado, internamente com indumento, externamente glabras, margem ciliada; hipanto prolongado acima do ovário, externamente glabro. Baga madura 4-6 $\times 3,5-6,5 \mathrm{~mm}$, globosa, glabra.

Material selecionado: Capitólio, Serra de Furnas, morro atrás da pousada do Rio Turvo, 21.V.2007, J.N. Nakajima et al. 4417 (HUFU).

Esta espécie apresenta ampla distribuição, ocorrendo desde Trinidad Tobago até Uruguai e Paraguai (Govaerts et al. 2008). Além do campo rupestre, também pode ser encontrada em floresta semidecidual e capoeira (Morais \& Lombardi 2006).

Myrcia multiflora caracteriza-se pelas folhas discolores, com nervuras evidentes, nigrescentes e pontuações em ambas as faces da lâmina. 

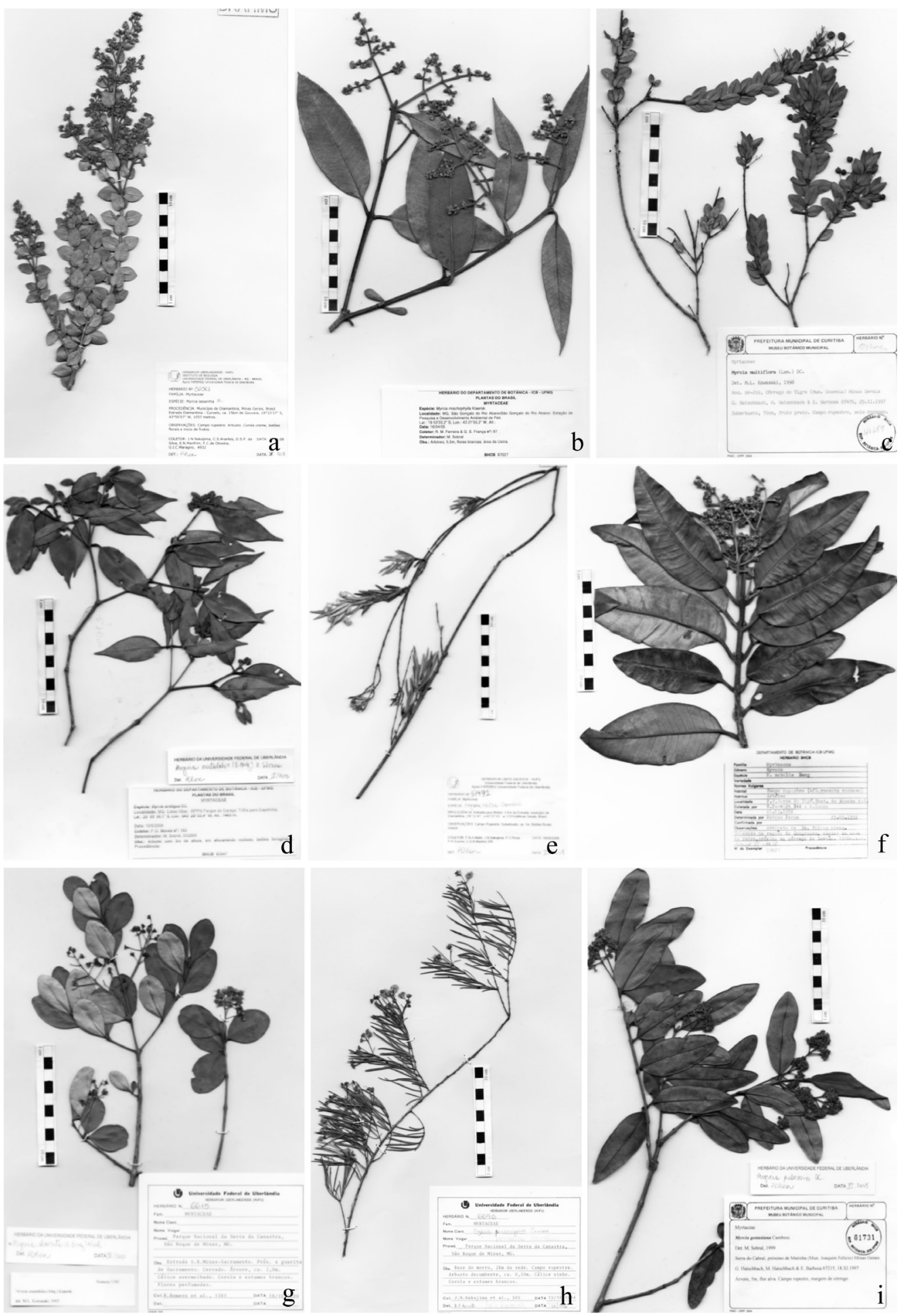

Figura 2 - a. Myrcia lasiantha DC.; b. M. mischophylla Kiaersk.; c. M. multiflora (Lam.) DC.; d. M. mutabilis (O. Berg) N. Silveira; e. M. nivea Cambess.; f. M. nobilis O. Berg; g. M. obovata (O. Berg) Nied.; h. M. pinifolia Cambess.; i. M. pubescens DC.

Figure 2 - a. Myrcia lasiantha DC.; b. M. mischophylla Kiaersk.; c. M. multiflora (Lam.) DC.; d. M. mutabilis (O. Berg) N. Silveira; e. M. nivea Cambess.; f. M. nobilis O. Berg; g. M. obovata (O. Berg) Nied.; h. M. pinifolia Cambess.; i. M. pubescens DC. 
13. Myrcia mutabilis (O. Berg) N. Silveira, Loefgrenia 88: 1. 1985.

Fig. $2 \mathrm{~d}$

Árvores, 3-8 m alt. Ramos não nodosos, cilíndricos, descamantes, cinéreos, ramos apicais com indumento ferrugíneo, persistente, gemas recobertas por catafilos ferrugíneo-tomentosos. Folhas opostas, concolores, não congestas no ápice dos ramos, pecíolo canaliculado, 5-12 mm compr.; lâmina 4-11,5 × 2-5 cm, cartácea, elíptica a ovada, ápice acuminado, margem não revoluta, base oblíqua a atenuada, face adaxial glabrescente, face abaxial com indumento esparso, ferrugíneo a nigrescente. Panículas paucifloras, axilares ou terminais, flores não aglomeradas no ápice da inflorescência; botões florais 2-4,5 × 2-5 mm, obovados, pilosos; brácteas e bractéolas caducas; pétalas alvas; cálice fechado no botão, 4-(5)mero, sépalas rompem irregularmente, interna e externamente com indumento, margem ciliada; hipanto prolongado acima do ovário, externamente piloso. Baga madura, 3-6 × 3-8 mm, globosa, glabrescente, vinácea.

Material selecionado: Carrancas, Cachoeira da Fumaça, 9.XII. 1983, H.F. Leitão-Filho et al. 15414 (UEC).

Espécie com distribuição no Nordeste, Sudeste e na porção central do Brasil (Govaerts et al. 2008). Em Minas Gerais ocorre em floresta ciliar (Kawasaki 1989; Peron 1994) e campo rupestre (Peron 1994; Morais \& Lombardi 2006).

Myrcia mutabilis é prontamente reconhecida pelos ramos apicais com indumento ferrugíneo e catafilos que recobrem a gema apical, além das sépalas que se rompem irregularmente.

14. Myrcia nivea Cambess., Flora Brasiliae Meridionalis.2: 332. 1832.

Fig. 2e

Subarbustos 0,4-1,2 m alt. Ramos não nodosos, cilíndricos, inferiores descamantes, ramos apicais com indumento lanoso, cinéreo, persistente, gema apical não recoberta por catafilos. Folhas alternas ou verticiladas, concolores, não congestas no ápice dos ramos, subsésseis ou pecíolo canaliculado até $3 \mathrm{~mm}$ compr.; lâmina 0,5-5,5 × $0,2-1,5 \mathrm{~cm}$, coriácea, lanceolada a linear, ápice arredondado, margem revoluta, base cuneada, face adaxial com indumento apenas na nervura principal das folhas mais velhas, face abaxial com indumento cinéreo, pontuações translúcidas visíveis em ambas as faces, ambas as faces das folhas jovens com indumento. Flores solitárias, axilares, $1-3$, não aglomeradas no ápice da inflorescência; botões florais 3-6 mm compr., globosos, pilosos; brácteas e bractéolas caducas; pétalas róseas; cálice aberto no botão, 5-mero, sépalas 1-4 mm compr., ápice acuminado, interna e externamente com indumento, margem ciliada; hipanto prolongado acima do ovário, externamente piloso. Baga madura 7-10 $\times 7-10 \mathrm{~mm}$, globosa, glabrescente, vinácea, verrucosa.

Material selecionado: São Roque de Minas, Parque Nacional da Serra da Canastra, Guarita de Sacramento, 20.IX.1996, R. Romero \& J.N. Nakajima 3589 (HUFU).

Myrcia nivea ocorre nos estados de Minas Gerais, Goiás, Bahia e no Distrito Federal (Sobral et al. 2010). No estado de Minas Gerais é amplamente distribuída nas serras de Diamantina e no Parque Nacional da Serra da Canastra.

Espécie prontamente reconhecida pelos ramos apicais com indumento lanoso, folhas de margem revoluta e pétalas róseas.

15. Myrcia nobilis O. Berg, in Mart., Eichler \& Urban, Flora brasiliensis 14(1): 195. 1857.

Fig. $2 \mathrm{f}$

Arvoretas ou árvores, 2-3 m alt. Ramos não nodosos, quadrangulares, achatados, descamantes, indumento ocráceo a nigrescente, persistente, gema apical não recoberta por catafilos. Folhas opostas, concolores, não congestas no ápice dos ramos, pecíolo canaliculado, 10-20 mm compr.; lâmina 1-17 × 3,5-5,5 cm, coriácea, lanceolada a ovada, ápice agudo, margem ondulada, base atenuada, face adaxial com indumento esparso na nervura principal, face abaxial com nervuras proeminentes e indumento ocráceo a nigrescente. Panículas multifloras, axilares ou subterminais, flores não aglomeradas no ápice da inflorescência; botões florais 4-6 × 3-4 mm, globosos, pilosos; brácteas e bractéolas caducas; pétalas alvas; cálice aberto no botão, 5-mero, sépalas 1,5-2 $\mathrm{mm}$ compr., ápice arredondado, interna e externamente com indumento, margem ciliada; hipanto prolongado acima do ovário, externamente piloso. Baga madura 3-6 × 3-7 mm, globosa, pilosa, alaranjada, rugosa.

Material selecionado: Diamantina, Biribiri, 19.X.2007, F.N.A. Mello et al. 85 (HUFU).

Segundo Sobral et al. (2010), Myrcia nobilis ocorre nos estados de Minas Gerais e Mato Grosso e dados de herbário mostram que esta espécie também ocorre na Bahia. Em Minas Gerais, além de campo rupestre, é frequentemente encontrada em floresta de altitude (Kawasaki 1989; Morais \& Lombardi 2006). 
Myrcia nobilis distingue-se das demais espécies pelas folhas e pecíolos maiores, além da nervura proeminente e o indumento ocráceo a nigrescente na face abaxial da lâmina.

16. Myrcia obovata (O. Berg) Nied., in Die Natürlichen Pflanzenfamilien 3, Abt. 7: 76. 1893.

Fig. $2 \mathrm{~g}$

Arbustos ou árvores, 0,5-2,5 m alt. Ramos não nodosos, cilíndricos, não descamantes, glabros, cobertos por pontuações visíveis por todo ramo, gema apical não recoberta por catafilos. Folhas opostas, discolores, não congestas no ápice dos ramos, pecíolo canaliculado, 3-7 mm compr.; lâmina $1-5,5 \times 0,5-3,5 \mathrm{~cm}$, coriácea, marrom escura depois de herborizada, ovada a obovada, ápice arredondado, margem não revoluta, base atenuada, ambas as faces glabras, pontuações translúcidas. Panículas multifloras, axilares ou subterminais, flores não aglomeradas no ápice da inflorescência; botões florais 2-4 × 1,5-3,5 $\mathrm{mm}$, claviformes, glabros; brácteas e bractéolas caducas; pétalas alvas; cálice aberto no botão, 5-mero, sépalas até $1 \mathrm{~mm}$ compr., ápice obtuso a arredondado, internamente com indumento, externamente glabras, margem ciliada; hipanto prolongado acima do ovário, externamente glabro. Baga madura 4-6 × 3-6 mm, globosa, glabra, verrucosa.

Material selecionado: São Roque de Minas, Parque Nacional da Serra da Canastra, 18.X.1994, R. Romero et al. 1402 (HUFU).

Segundo Sobral et al. (2010), Myrcia obovata ocorre nos estados de Minas Gerais e Bahia. Em Minas Gerais é comumente encontrada em floresta ciliar (Kawasaki 1989), floresta de galeria associadas a campo rupestre (Peron 1994) e campo rupestre (Morais \& Lombardi 2006).

Espécie facilmente reconhecida pelas folhas discolores, ovadas a obovadas, glabras e ramos e ambas as faces da lâmina recobertas por pontuações translúcidas.

17. Myrcia pinifolia Cambess., Flora Brasiliae Meridionalis 2: 333. 1832. Fig. $2 \mathrm{~h}$

Subarbustos ou arbustos, $0,2-0,5 \mathrm{~m}$ alt. Ramos não nodosos, cilíndricos, descamantes, marrom-avermelhados, glabros, gema apical não recoberta por catafilos. Folhas opostas, concolores, não congestas no ápice dos ramos, sésseis; lâmina 5-40 × 1-3 mm, coriácea, linear, ápice arredondado, margem revoluta, base atenuada, ambas as faces glabras, pontuações translúcidas. Panículas multifloras, axilares, flores não aglomeradas no ápice da inflorescência; botões florais $2-6 \times 2-5 \mathrm{~mm}$, claviformes, glabros; brácteas e bractéolas caducas; pétalas alvas; cálice aberto no botão, 5-mero, sépalas até $2 \mathrm{~mm}$ compr., ápice arredondado, interna e externamente glabras, margem glabra; hipanto prolongado acima do ovário, externamente glabro. Baga madura 3-7 × 2-9 mm, globosa, glabra, vinácea, verrucosa.

Material selecionado: São Roque de Minas, Parque Nacional da Serra da Canastra, Serra Brava, 28.IX.1995, R. Romero et al. 2982 (HUFU).

Segundo Sobral et al. (2010), Myrcia pinifolia está restrita aos estados de Goiás e Bahia. No presente estudo esta espécie é citada pela primeira vez para o estado de Minas Gerais.

Myrcia pinifolia caracteriza-se pelo hábito subarbustivo a arbustivo, ramos glabros, disposição das folhas sempre voltadas para um lado da planta e pontuações translúcidas por toda planta.

18. Myrcia pubescens DC., Prodromus 3: 247. 1828.

Fig. $2 \mathrm{i}$

Arvoretas ou árvores, 4-5 m alt. Ramos não nodosos, cilíndricos, descamantes, indumento cinéreo, nos ramos apicais dourado, glabrescente, gema apical não recoberta por catafilos. Folhas opostas, concolores, não congestas no ápice dos ramos, pecíolo canaliculado, 4-8 mm compr.; lâmina 4-9,5 × 1-3,5 cm, coriácea, marrom escura depois de herborizada, elíptica, ápice agudo a arredondado, margem revoluta, base cuneada, ambas as faces glabras, com pontuações translúcidas, nervura principal na face abaxial das folhas jovens com indumento dourado a ferrugíneo. Panículas paucifloras, axilares ou subterminais, flores aglomeradas no ápice da inflorescência; botões florais $2-4 \times 2-3 \mathrm{~mm}$, globosos, pilosos; brácteas e bractéolas caducas; pétalas alvas; cálice aberto no botão, 5-mero, sépalas ca. $1 \mathrm{~mm}$ compr., ápice arredondado, interna e externamente com indumento, margem ciliada; hipanto prolongado acima do ovário, externamente piloso. Fruto não visto.

Material selecionado: Grão Mogol, Bacia do Ribeirão da Morte, 4.XI.1987, R. Mello-Silva et al. 11477 (SP).

Myrcia pubescens ocorre na Bolívia e Brasil (Govaerts et al. 2008), em campo rupestre e floresta associada. 
As características diagnósticas desta espécie são o indumento na nervura principal da face abaxial da lâmina foliar, as flores aglomeradas no ápice da inflorescência e a coloração amarronzada após a herborização.

19. Myrcia pubiflora DC., Prodromus 3: 249. 1828.

Fig. 3a

Arbustos, 1-2 m alt. Ramos não nodosos, cilíndricos, não descamantes, indumento alvo, glabrescente, gema apical não recoberta por catafilos. Folhas opostas, concolores, não congestas no ápice dos ramos, pecíolo canaliculado, 4-6 $\mathrm{mm}$ compr.; lâmina 1-5 × 1-3 cm, coriácea, marrom escura depois de herborizada, elíptica a ovada, ápice obtuso, margem levemente revoluta, base atenuada a cuneada, ambas as faces glabrescentes, pontuações nigrescentes. Panículas paucifloras, axilares ou subterminais, flores não aglomeradas no ápice da inflorescência; botões florais 1,5-3 × ca. $2 \mathrm{~mm}$, obovados, pilosos; brácteas e bractéolas caducas; pétalas alvas; cálice aberto no botão, 5-mero, sépalas menores que $1 \mathrm{~mm}$ compr., ápice arredondado, interna e externamente glabras, margem glabra; hipanto prolongado acima do ovário, externamente glabro. Baga madura 3-7 × 4-6 mm, globosa, pilosa.

Material selecionado: Ouro Preto, Camarinhas, 27.III.1988, M. Peron 685 (SP).

Myrcia pubiflora ocorre na Bolívia, Paraguai e Brasil (Govaerts et al. 2008). Em Minas Gerais ocorre exclusivamente em campo rupestre.

Esta espécie caracteriza-se pelo hábito arbustivo, indumento glabrescente e pontuações translúcidas nas folhas, que quando secas tornamse nigrescentes e as folhas amarronzadas após herborizadas.

20. Myrcia pulchra (O. Berg) Kiaersk., Enumeratio Myrtacearum Brasiliensium 65. 1893. Fig. 3b

Arbustos ou árvores, 1,5-4 m alt. Ramos não nodosos, achatados no ápice, descamantes, ramos apicais com indumento ferrugíneo, persistente, gema apical não recoberta por catafilos. Folhas opostas, discolores, congestas no ápice dos ramos, pecíolo canaliculado, 5-10 $\mathrm{mm}$ compr.; lâmina 3,5-10,5 × 1-3,5 cm, cartácea, elíptica a lanceolada, ápice agudo a arredondado, margem não revoluta, base aguda, face adaxial glabrescente, com pontuações translúcidas, face abaxial com indumento ferrugíneo, maior concentração de indumento na nervura principal das folhas mais velhas. Panículas multifloras, subterminais, flores não aglomeradas no ápice da inflorescência; botões florais ca. $2 \times 2-3 \mathrm{~mm}$, claviformes, glabros; brácteas e bractéolas caducas; pétalas alvas; cálice aberto no botão, 4-mero, sépalas ca. $1 \mathrm{~mm}$ compr., ápice arredondado; interna e externamente glabras, margem glabra; hipanto prolongado acima do ovário, externamente glabro. Baga madura 3-6× 3-7 mm, globosa, glabra.

Material selecionado: São Roque de Minas, Parque Nacional da Serra da Canastra, 17.X.1994, J.N. Nakajima et al. 1508 (HUFU).

Sobral et al. (2010) citam esta espécie para os estados do Rio Grande do Sul, Santa Catarina, Paraná, Rio de Janeiro, São Paulo, Espírito Santo e Minas Gerais, enquanto dados de herbário mostram que $M$. pulchra também ocorre na Bahia. Nas serras mineiras foi coletada nas bordas de formações florestais associadas aos campos rupestres.

Myrcia pulchra é prontamente reconhecida pelas folhas discolores, elípticas a lanceoladas, de ápice agudo a arredondado, dispostas de forma congesta no ápice dos ramos e face abaxial da lâmina com indumento ferrugíneo, que se destaca com facilidade ao toque.

21. Myrcia racemulosa DC., Prodromus 3: 254. 1828.

Fig. 3c

Subarbustos, $0,6 \mathrm{~m}$ alt. Ramos não nodosos, cilíndricos, descamantes, glabros, gema apical não recoberta por catafilos. Folhas opostas, concolores, não congestas no ápice dos ramos, sésseis; lâmina 1,5-2,5 × 0,5-1,5 cm, cartácea, lanceolada, ápice agudo, margem não revoluta, base atenuada, ambas as faces glabras, com pontuações translúcidas. Racemos, axilares, flores não aglomeradas no ápice da inflorescência; botão floral ca. $3 \times 3 \mathrm{~mm}$, obovados, glabros; brácteas e bractéolas caducas; pétalas púrpuras; cálice aberto no botão, 5-mero, sépalas até $1 \mathrm{~mm}$ compr., ápice arredondado a agudo, interna e externamente glabras, margem ciliada; hipanto prolongado acima do ovário, externamente glabro. Fruto não visto.

Material selecionado: Joaquim Felício, Serra do Cabral, 18.XI.1997, G. Hatchbach et al. 67232 (BHCB).

Espécie com distribuição na Região Sudeste e Centro-Oeste do Brasil (Govaerts et al. 2008), em campo rupestre e Cerrado.

Myrcia racemulosa apresenta inflorescência do tipo racemo e os ramos da inflorescência, botão floral e pétalas purpúreos. 

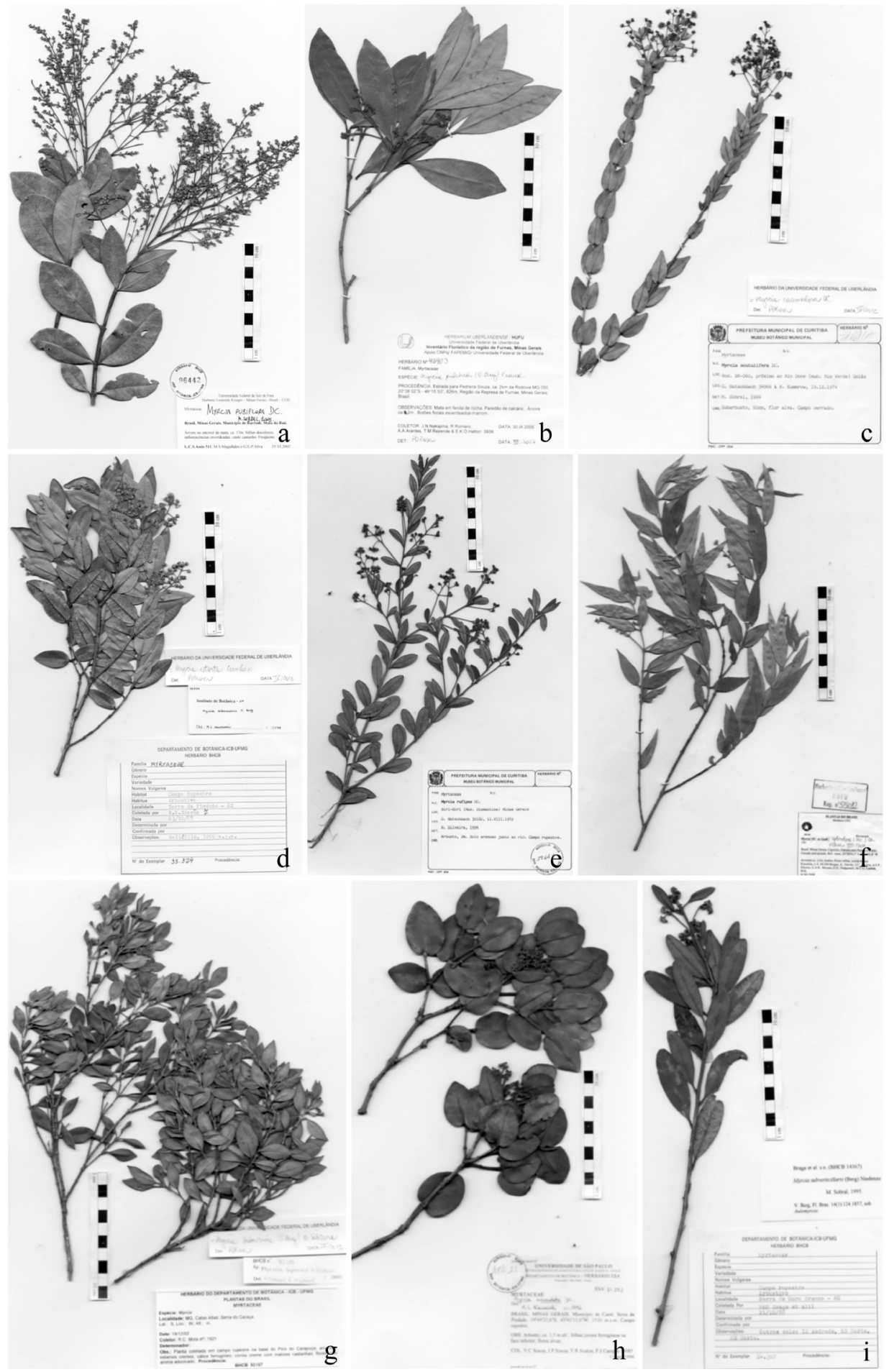

Figura 3 - a. Myrcia pubiflora DC.; b. M. pulchra (O. Berg) Kiaersk.; c. M. racemulosa DC.; d. M. retorta Cambess.; e. M. rufipes DC.; f. M. splendens (Sw.) DC.; g. M. subavenia (O. Berg) N. Silveira; h. M. subcordata DC.; i. M. subverticillaris (O. Berg) Kiaersk.

Figure 3 - a. Myrcia pubiflora DC.; b. M. pulchra (O. Berg) Kiaersk.; c. M. racemulosa DC.; d. M. retorta Cambess.; e. M. rufipes DC.; f. M. splendens (Sw.) DC.; g. M. subavenia (O. Berg) N. Silveira; h) M. subcordata DC.; i. M. subverticillaris (O. Berg) Kiaersk. 
22. Myrcia retorta Cambess., Flora Brasiliae Meridionalis. 2: 322. 1832.

Fig. 3d

Arbustos ou árvores, 1,5-6 m de alt. Ramos não nodosos, cilíndricos, não descamantes, ramos apicais com indumento pardacento, posteriormente nigrescente, persistente, gema apical não recoberta por catafilos. Folhas opostas, discolores, não congestas no ápice dos ramos, pecíolo canaliculado, 2-5 mm compr.; lâmina 0,5-5 × 0,5-2 cm, cartácea a coriácea, lanceolada, ápice agudo a arredondado, margem levemente revoluta, base cuneada, face adaxial com indumento esparso na nervura principal, face abaxial com indumento pardacento, ambas as faces com pontuações translúcidas a nigrescentes. Panículas multifloras, axilares ou subterminais, flores não aglomeradas no ápice da inflorescência; botões florais 3-4 × 2-4 mm, globosos, pilosos; brácteas e bractéolas caducas; pétalas alvas; cálice aberto no botão, 5-mero, sépalas 1-2 mm compr., ápice arredondado a acuminado, internamente glabras, externamente com indumento, margem ciliada; hipanto prolongado acima do ovário, externamente piloso. Baga madura $1-5 \times 1-5 \mathrm{~mm}$, globosa, glabrescente, verrucosa.

Material selecionado: Diamantina, Conselheiro Mata, trilha para Cachoeira das Fadas, 21.X.2007, P.O. Rosa et al. 969 (HUFU).

Segundo Sobral et al. (2010), M. retorta distribui-se nas regiões Sudeste e Sul do Brasil. Em Minas Gerais, esta espécie é comumente encontrada em campo rupestre e floresta nebular (Morais \& Lombardi 2006).

Myrcia retorta é prontamente reconhecida pelas folhas jovens com indumento pardacento na face abaxial com pontuações alvas que vão se tornando nigrescentes e se destacam com facilidade ao toque.

\section{Myrcia rufipes DC., Prodromus 3: 247.} 1828.

Fig. 3e

Subarbustos ou arbustos, 0,8-2 $\mathrm{m}$ alt. Ramos não nodosos, achatados no ápice, não descamantes, indumento ferrugíneo a ocráceo, persistente, gema apical não recoberta por catafilos. Folhas opostas, discolores, não congestas no ápice dos ramos, pecíolo canaliculado, 2-6 mm compr.; lâmina $1-9 \times 0,5-3,5 \mathrm{~cm}$, cartácea, elíptica a obovada, ápice agudo a arredondado, margem levemente revoluta, base cuneada, ambas as faces das folhas jovens com indumento avermelhado a ocráceo, face adaxial glabrescente, com pontuações nigrescentes. Panículas multifloras, axilares ou terminais, flores não aglomeradas no ápice da inflorescência; botões florais 1-3 × 1-4 mm, obovados, glabrescentes; brácteas e bractéolas caducas; pétalas alvas; cálice aberto no botão, 5-mero, sépalas 1-2 mm compr., ápice arredondado ou agudo, internamente com indumento, externamente glabras, margem ciliada; hipanto prolongado acima do ovário, externamente piloso. Baga madura 3-7 × 3-9 mm, globosa, glabra, vinácea a nigrescente.

Material selecionado: Botumirim, Serra da Canastra, estrada para Adão Colares-Barrocão, 20.XI.1992, R. Mello-Silva et al. 729 (SP).

Segundo Sobral et al. (2010), Myrcia rufipes distribui-se pelos estados do Piauí, Bahia, Alagoas, Goiás, Minas Gerais, Espírito Santo e São Paulo. É frequentemente encontrada em campo cerrado, floresta (Kawasaki 1989), cerrado (Peron 1994), floresta semidecidua e capoeira (Morais \& Lombardi 2006) do estado de Minas Gerais.

Myrcia rufipes pode ser facilmente reconhecida pelas folhas cartáceas, jovens com indumento avermelhado a ocráceo em ambas as faces e pontuações nigrescentes visíveis.

24. Myrcia splendens (Sw.) DC., Prodromus 3: 244. 1828.

Fig. $3 f$

Arbustos ou árvores, 1,5-6 m alt. Ramos não nodosos, cilíndricos, não descamantes, indumento creme a nigrescente, glabrescente, gema apical não recoberta por catafilos. Folhas opostas, concolores, não congestas no ápice dos ramos, pecíolo geralmente canaliculado, $1-7 \mathrm{~mm}$ compr.; lâmina 0,5-14,5 × 0,3-5 cm, cartácea ou coriácea, elíptica a lanceolada, ápice acuminado, margem não revoluta, base cuneada, ambas as faces glabrescentes, indumento presente apenas na nervura principal, folhas jovens cobertas por indumento em ambas as faces. Panículas multifloras, axilares ou terminais, flores não aglomeradas no ápice da inflorescência; botões florais 1-5 × 2-3 mm, globosos, glabros; brácteas e bractéolas caducas; pétalas alvas; cálice aberto no botão, 5-mero, sépalas 1-2 mm compr., ápice acuminado, externamente com indumento denso, internamente esparso, margem ciliada; hipanto não prolongado acima do ovário. Baga madura 3-11 $\times$ 3-7 mm, elipsóide, glabrescente, verrucosa.

Material selecionado: Rio Vermelho, Fazenda Vargem do Machado, 8.VII.1986, M.S. Meneandro 96 (BHCB).

Espécie com ampla distribuição, ocorrendo desde o México até o Brasil, Paraguai e Argentina (Govaerts et al. 2008). Myrcia splendens ocorre em praticamente todas as fitosionomias do 
bioma Cerrado, sendo comumente encontrada em floresta ciliar, capões (Kawasaki 1989), campo rupestre, floresta semidecidual (Morais \& Lombardi 2006), de galeria, Cerrado e cerradão (Arantes \& Monteiro 2002).

Myrcia splendens é prontamente reconhecida pelas folhas elípticas a lanceoladas, de ápice acuminado e ambas as faces da folha glabrescentes. O binômio $M$. splendens conta com ca. de 150 sinônimos, dentre os quais é importante citar M. fallax (Rich.) DC. e M. rostrata DC., os mais conhecidos.

25. Myrcia subavenia (O. Berg) N. Silveira, Roessleria 7(1): 66. 1985.

Fig. $3 g$

Subarbustos xilopodíferos, arbustos ou arvoretas, 0,2-2,5 m alt. Ramos nodosos, cilíndricos, descamantes ou não, indumento cinéreo, glabrescente, persistente apenas na ráquis, gema apical não recoberta por catafilos. Folhas opostas, concolores, pecíolo canaliculado, 2-8 mm compr.; lâmina 0,5-7 ×0,1-2 cm, membranácea, marrom escura depois de herborizada, elíptica a lanceolada, ápice agudo a arredondado, margem levemente revoluta ou não, base atenuada, ambas as faces das folhas jovens com indumento cinéreo, face abaxial glabrescente, face adaxial glabra, com pontuações nigrescentes. Dicásios, axilares ou terminais, flores não aglomeradas no ápice da inflorescência; botões florais 2-6 × 2-5 mm, turbinados, glabros ou pilosos; brácteas e bractéolas caducas; pétalas alvas; cálice aberto no botão, 5-mero, sépalas 1-5 mm compr., ápice obtuso a acuminado; interna e externamente glabras, margem ciliada; hipanto prolongado acima do ovário, externamente piloso. Baga madura 2-7 $\times$ 1,5-8 mm, globosa, glabrescente.

Material selecionado: São Roque de Minas, Parque Nacional da Serra da Canastra, 22.IX.1996, R. Romero \& J.N. Nakajima 3599 (HUFU).

Segundo Sobral et al. (2010), M. subavenia é endêmica do estado de Minas Gerais, ocorrendo em Cerrado e Floresta Atlântica, mas dados de herbário mostram que também ocorre em campo rupestre na Bahia.

Myrcia subavenia difere das demais espécies de Myrcia por apresentar xilopódio, inflorescência do tipo dicásio e botões florais turbinados.

26. Myrcia subcordata DC., Prodromus 3: 253. 1828.

Fig. $3 \mathrm{~h}$

Arbustos ou árvores, 1-4 m alt. Ramos não nodosos, cilíndricos, descamantes, ramos apicais com indumento nigrescente, glabrescente, gema apical não recoberta por catafilos. Folhas opostas, concolores, não congestas no ápice dos ramos, sésseis; lâmina 2-5,5 × 1-3,5 cm, coriácea, marrom escura depois de herborizada, ovada, ápice arredondado a agudo, margem levemente revoluta, base cordada a subcordada, face adaxial glabra, face abaxial com indumento esparso, ferrugíneo a nigrescente. Panículas multifloras, axilares ou subterminais, flores não aglomeradas no ápice da inflorescência; botões florais 2-3 × 1-2 mm, obovados, pilosos; brácteas e bractéolas caducas; pétalas alvas; cálice aberto no botão, 5-mero, sépalas ca. 0,5 mm compr., ápice arredondado, interna e externamente com indumento, margem ciliada; hipanto prolongado acima do ovário, externamente glabro. Baga madura 2-6 × 2,5-7 mm, globosa, glabrescente.

Material selecionado: São Tomé das Letras, próximo à cidade, 10.II.1986, C. Farney 1079 (SP).

Espécie restrita ao estado de Minas Gerais (Sobral et al. 2010), ocorrendo em afloramento quartzítico, floresta ciliar (Peron 1994), campo rupestre e capoeira (Morais \& Lombardi 2006) da Serra do Espinhaço e em campos de altitude na Serra do Caparaó.

Myrcia subcordata é facilmente reconhecida pelas folhas ovadas, de base cordada a subcordada, disposição nos ramos formando um ângulo de $90^{\circ}$ e folhas amarronzadas após herborizadas.

27. Myrcia subverticillaris (O. Berg) Kiaersk., in Enumeratio Myrtacearum Brasiliensium 88. 1893.

Fig. $3 \mathrm{i}$

Subarbustos, arbustos ou arvoretas, 0,6-3 m alt. Ramos não nodosos, cilíndricos, descamantes, ramos apicais com indumento ocráceo ou ferrugíneo, persistente, gema apical não recoberta por catafilos. Folhas alternas na base dos ramos, opostas no ápice, concolores, não congestas no ápice dos ramos, pecíolo canaliculado, 5-8 mm compr.; lâmina 2-6 $\times 0,5-2 \mathrm{~cm}$, cartácea, elíptica ou oblonga, ápice arredondado, margem não revoluta, base atenuada a aguda, face adaxial glabra, com pontuações translúcidas, indumento denso, avermelhado e persistente na face abaxial. Panículas paucifloras, axilares, flores não aglomeradas no ápice da inflorescência; botões florais $1-2 \times$ ca. $1 \mathrm{~mm}$, obovados, pilosos; brácteas e bractéolas caducas; pétalas alvas; cálice aberto no botão, 5-mero, sépalas ca. 0,5 mm compr., ápice obtuso a arredondado, interna e externamente com indumento, margem glabra; hipanto prolongado acima do ovário, externamente piloso. Frutos não vistos. 
Material selecionado: Ouro Branco, Morro do Gabriel, 8.III.1995, V.C. Souza et al. 7934 (SP).

Govaerts et al. (2008) citam esta espécie para as Regiões Sudeste, Centro-Oeste e Nordeste do Brasil. Em Minas Gerais, Myrcia subverticillaris é frequente em campo rupestre e formações florestais das Serras de Ouro Branco e Ouro Preto.

Esta espécie é muito próxima de Myrcia rufipes, da qual se diferencia, principalmente, pelas folhas alternas na base dos ramos em $M$. subverticillaris e opostas em $M$. rufipes.

28. Myrcia tomentosa (Aubl.) DC., Prodromus 3: 245. 1828.

Fig. 4a

Arbustos ou árvores, 1,2-7 m alt. Ramos não nodosos, cilíndricos, descamantes, indumento cinéreo, persistente, ramos apicais pruinosos, gema apical não recoberta por catafilos. Folhas opostas, concolores, não congestas no ápice dos ramos, pecíolo canaliculado, 5-18 mm compr.; lâmina $1-11,5 \times 0,5-5 \mathrm{~cm}$, cartácea, elíptica a lanceolada ou obovada, ápice agudo a mucronulado, margem ondulada depois de seca, base cuneada a oblíqua, ambas as faces com indumento cinéreo pruinoso, face adaxial com pontuações nigrescentes. Panículas multifloras, axilares ou subterminais, flores sésseis, não aglomeradas no ápice da inflorescência; botões florais 1-3 × 1-2 mm, obovados, pilosos; brácteas e bractéolas caducas; pétalas alvas; cálice aberto no botão, 5-mero, sépalas 1-2 mm compr., ápice agudo, externamente com indumento, internamente glabras, margem ciliada; hipanto prolongado acima do ovário, externamente glabro. Baga madura 2-8 $\times$ 3-7 mm, globosa, glabrescente, amarelada.

Material selecionado: Ouro Preto, 18.X.2007, A.P.M. Santos et al. 431 (HUFU).

Espécie com distribuição em Trinidad e Tobago, Panamá e Brasil (Govaerts et al. 2008), ocorrendo em floresta ciliar (Kawasaki 1989), cerrado, campo rupestre (Peron 1994), floresta semidecidual (Morais \& Lombardi, 2006), cerradão, campo cerrado e campo sujo (Arantes \& Monteiro 2002), frequentemente associada aos cursos d'água ou bordas de formações florestais.

Myrcia tomentosa é facilmente reconhecida pelas folhas cartáceas, com indumento pruinoso, flores sésseis e frutos amarelados quando maduros.

29. Myrcia uberavensis O. Berg, in Mart., Eichler \& Urban, Flora brasiliensis 14(1): 568. 1859.

Fig. $4 b$

Subarbustos ou arbustos, 0,5-1,2 $\mathrm{m}$ alt. Ramos não nodosos, cilíndricos, descamantes, achatados no ápice, indumento castanho-dourado, persistente, gema apical não recoberta por catafilos. Folhas opostas cruzadas, concolores, não congestas no ápice dos ramos, sésseis ou pecíolo canaliculado de até $2 \mathrm{~mm}$; lâmina 2,5-9,5 × 1,5-5 $\mathrm{cm}$, coriácea, ovada, ápice agudo, margem não revoluta, base cordada, face adaxial glabrescente, face abaxial e ambas as faces das folhas jovens com indumento dourado, pontuações translúcidas. Panículas multifloras, compostas do tipo tirsóide, axilares, subterminais ou terminais, flores não aglomeradas no ápice da inflorescência; botões florais 3-5 × 2-4 mm, claviforme, pilosos; brácteas e bractéolas caducas, pétalas alvas; cálice aberto no botão, 5-mero, sépalas 1-2 mm compr., ápice agudo, internamente glabras, externamente com indumento, margem ciliada; hipanto prolongado acima do ovário, externamente piloso. Baga madura 9-15 × 3-5 mm, elipsóide, glabrescente.

Material selecionado: Ibiraci, Serra de Furnas, 6.IX.1998, V.C. Souza et al. 21203 (SP).

Myrcia uberavensis distribui-se nas Regiões Sudeste e Centro-Oeste do Brasil (Sobral et al. 2010) e além de campo rupestre, ocorre também em campo sujo e Cerrado (Arantes \& Monteiro 2002) do estado de Minas Gerais.

Esta espécie é prontamente reconhecida pelas panículas compostas do tipo tirsóide, ramos com indumento castanho-dourado e frutos elipsóides.

30. Myrcia variabilis Mart. ex DC., Prodromus 3: 254. 1828 .

Fig. 4c

Árvores até $4 \mathrm{~m}$ alt. Ramos não nodosos, cilíndricos, descamantes, marrom-avermelhados, glabros, gema apical não recoberta por catafilos. Folhas opostas cruzadas, discolores, não congestas no ápice dos ramos, sésseis; lâmina 0,5-7 × 0,5-4 cm, coriácea, marrom escura depois de herborizada, oblonga a cordada, ápice agudo a obtuso, margem não revoluta, base cordada, ambas as faces glabras, pontuações translúcidas. Panículas multifloras, axilares ou subterminais, flores não aglomeradas no ápice da inflorescência; botões florais 2-4 × 2-4 mm, globosos, glabros; brácteas e bractéolas caducas; pétalas alvas; cálice aberto no botão, 5-mero, sépalas ca. 1 mm compr., ápice agudo a obtuso, internamente com indumento, externamente glabras, margem glabra; hipanto prolongado acima do ovário, externamente glabro. Baga madura 2-7 × 1-6 mm, globosa, glabra, verrucosa-glandular. 

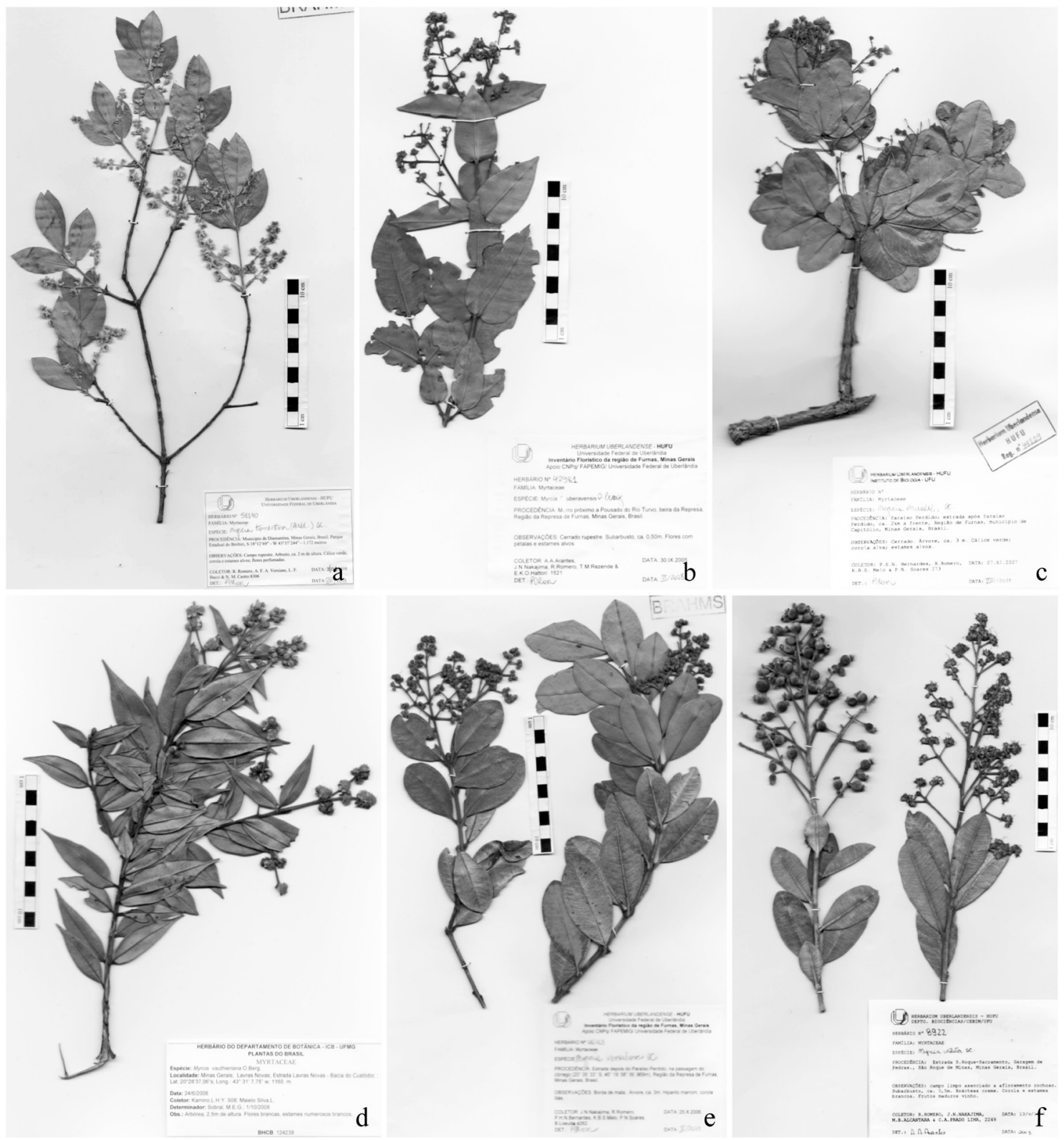

Figura 4 -a. Myrcia tomentosa (Aubl.) DC.; b. M. uberavensis O. Berg; c. M. variabilis Mart. ex DC.; d. M. vauthiereana O. Berg; e. M. venulosa DC.; f. M. vestita DC.

Figure 4 - a. Myrcia tomentosa (Aubl.) DC.; b. M. uberavensis O. Berg; c. M. variabilis Mart. ex DC.; d. M. vauthiereana O. Berg; e. M. venulosa DC.; f. M. vestita DC.

Material selecionado: Delfinópolis, 25.X.2003, J.N. Nakajima et al. 3699 (HUFU).

Segundo Govaerts et al. (2008), Myrcia variabilis distribui-se por todas as regiões do Brasil, exceto no sul do país, mas dados de herbário mostram sua ocorrência no estado do Paraná. Em Minas Gerais, além do campo rupestre, ocorre também em Cerrado (Kawasaki 1989), campo sujo, campo cerrado e borda de cerradão (Arantes \& Monteiro 2002).

Myrcia variabilis apresenta hábito arbóreo, tronco retorcido característico das árvores de Cerrado, folhas sésseis, glabras, com pontuações translúcidas. 
31. Myrcia vauthiereana $\mathrm{O}$. Berg, in Mart., Eichler \& Urban, Flora brasiliensis 14(1): 154. 1857.

Fig. $4 d$

Arvoretas ou árvores, 2,5-8 $\mathrm{m}$ de alt. Ramos não nodosos, cilíndricos, descamantes, indumento ferrugíneo, glabrescente, gema apical não recoberta por catafilos. Folhas opostas, discolores, não congestas no ápice dos ramos, pecíolo canaliculado, 3-6 mm; lâmina 3,5-6 × 2-3 cm, coriácea, lanceolada, ápice acuminado, margem levemente revoluta, base obtusa a arredondada, face adaxial glabra, com pontuações translúcidas, face abaxial glabrescente, indumento esparso apenas na nervura principal. Racemos, axilares ou subterminais, flores não aglomeradas no ápice da inflorescência; botões florais 3-4 × ca. $3 \mathrm{~mm}$, globosos, pilosos; brácteas e bractéolas persistentes; pétalas alvas; cálice aberto no botão, 5-mero, sépalas 2-3 mm compr., ápice obtuso a arredondado, externamente com indumento, internamente glabras, margem glabra; hipanto não prolongado acima do ovário. Baga madura 5-10 × 3-6 mm, elipsóide, pilosa.

Material selecionado: Ouro Preto, Taquaral, 9.X.1892, P. Schwacke 8677 (RB).

Myrcia vauthiereana apresenta distribuição no Sudeste do Brasil (Govaerts et al. 2008) e, além do campo rupestre, ocorre também em floresta ciliar e capoeira (Peron 1994) do estado de Minas Gerais.

Myrcia eriopus, $M$. splendens e $M$. vauthiereana são muito próximas e características do indumento e das folhas permitem distingui-las. Myrcia eriopus apresenta folhas membranáceas e indumento hirsuto ferrugíneo nos ramos, enquanto M. splendens apresenta folhas cartáceas a coriáceas e indumento creme a nigrescente. Já $M$. vauthiereana apresenta folhas coriáceas e indumento ferrugíneo.

32. Myrcia venulosa DC., Prodromus 3: 250. 1828.

Fig. $4 \mathrm{e}$

Árvores, 2-8 m alt. Ramos não nodosos, cilíndricos, não descamantes, indumento ocráceo, persistente, gema apical não recoberta por catafilos. Folhas opostas, concolores, não congestas no ápice dos ramos, pecíolo canaliculado, 4-6 mm compr.; lâmina $0,5-7 \times 0,3-2,5 \mathrm{~cm}$, coriácea, elíptica a obovada, ápice agudo a arrendodado, margem não revoluta, base cuneada, face adaxial glabrescente, com pontuações nigrescentes, face abaxial com indumento ocráceo. Panículas multifloras, axilares ou terminais, flores não aglomeradas no ápice da inflorescência; botões florais $2-4 \times 2-3 \mathrm{~mm}$, obovados, pilosos; brácteas e bractéolas caducas; pétalas alvas; cálice aberto no botão, 5-mero, sépalas até $2 \mathrm{~mm}$ compr., ápice arredondado, interna e externamente com indumento, margem ciliada; hipanto prolongado acima do ovário, externamente piloso. Baga madura 6-7 × 5-7 mm, globosa, glabrescente.

Material selecionado: Santa Bárbara, Serra do Caraça, 12.XII.1978, H.F. Leitão-Filho et al. 9591 (MBM).

Segundo Sobral et al. (2010), Myrcia venulosa ocorre nos estados da Bahia, Goiás, Minas Gerais, Espírito Santo, São Paulo, Rio de Janeiro, Paraná e Santa Catarina. Myrcia venulosa também ocorre comumente em floresta ciliar (Kawasaki 1989), capão (Peron 1994), floresta semidecidual (Morais \& Lombardi 2006) e interior de floresta de galeria (Arantes \& Monteiro 2002) do estado de Minas Gerais. No presente estudo também foi encontrada em campo rupestre.

Myrcia venulosa diferencia-se de $M$. rufipes, da qual é bastante próxima, pelo hábito essencialmente arbóreo e indumento ocráceo, denso nos ramos e folhas.

33. Myrcia vestita DC., Prodromus 3: 248. 1828. Fig. $4 \mathrm{f}$

Subarbustos, 0,4-0,8 m alt. Ramos não nodosos, cilíndricos, não descamantes, indumento dourado a nigrescente, persistente, gema apical não recoberta por catafilos. Folhas alternas, raro verticiladas, discolores, não congestas no ápice dos ramos, pecíolo canaliculado, até $4 \mathrm{~mm}$ compr.; lâmina 2-10 × 1-5,5 cm, coriácea, elíptica a ovada, ápice arredondado a agudo, margem não revoluta, base aguda ou obtusa, face adaxial glabrescente, indumento na nervura principal, pontuações nigrescentes, face abaxial com indumento dourado a nigrescente, ambas as faces das folhas jovens com indumento pardo. Panículas multifloras, terminais, flores não aglomeradas no ápice da inflorescência; botões florais ca. $3 \times 3-4 \mathrm{~mm}$, globosos, pilosos; brácteas e bractéolas caducas; pétalas alvas; cálice aberto no botão, 5-mero, sépalas até $2 \mathrm{~mm}$ compr., ápice agudo, externamente com indumento, internamente glabras, margem glabra; hipanto prolongado acima do ovário, externamente piloso. Baga madura 4-11 × 3-10 mm, globosa, glabrescente, vinácea a nigrescente.

Material selecionado: Lagoa Santa, Serra do Cipó, VII.1937, Prof. Burret 15973 (RB).

Segundo Govaerts et al. (2008), esta espécie ocorre nas Regiões Nordeste, Sudeste e CentroOeste do Brasil e dados de herbário mostram sua ocorrência também no Paraná. Myrcia vestita é 
típica dos cerrados de Minas Gerais e Goiás (Peron 1994), tendo sido encontrada também em borda de floresta ciliar associada a campo rupestre.

Myrcia vestita é facilmente diferenciada das demais espécies pelas folhas discolores, ramos e folhas com indumento dourado a nigrescente e panículas essencialmente terminais.

\section{Agradecimentos}

Aos curadores dos herbários BHCB, MBM, OUPR, RB, SP, SPF e UEC, o acesso aos acervos e empréstimos concedidos. Ao Dr. Marcos Sobral por disponibilizar fotografias dos tipos de Myrtaceae e o auxílio na identificação e confirmação das espécies. Ao Dr. Jimi Nakajima o apoio nas expedições de campo, a Ana Paula Milla, Polyana Noronha e Carlos Eduardo, o auxílio durante as coletas. Ao Herbarium Uberlandense, onde estão depositados os espécimes coletados, por disponibilizar a estrutura física para o desenvolvimento do presente estudo. À Fundação de Amparo à Pesquisa do Estado de Minas Gerais (FAPEMIG proc. CRA1279/06), pelo apoio financeiro para a realização das expedições de coleta e visitas aos herbários.

\section{Referências}

Alves, R.J.V. \& Kolbek, J. 2009. Summit vascular flora of Serra de São José, Minas Gerais, Brazil. Check List 5: 35-73.

Arantes, A.A. \& Monteiro, R. 2002. A Família Myrtaceae na Estação Ecológica do Panga, Uberlândia, Minas Gerais, Brasil. Lundiana 3: 111-127.

Berg, O. 1857. Myrtaceae. In: Martius, C.P.F. (ed.). Flora brasiliensis 14: 1-468.

Berg, O. 1858. Myrtaceae. In: Martius, C.P.F. (ed.). Flora brasiliensis 14: 469-528.

Berg, O. 1859. Myrtaceae. In: Martius, C.P.F. (ed.). Flora brasiliensis 14: 529-656.

Conceição, A.A. \& Pirani, J.R. 2007. Diversidade em quatro áreas de campos rupestres na Chapada Diamantina, Bahia, Brasil: Espécies distintas, mas riquezas similares. Rodriguésia 58: 193-206.

Conceição, A.A.; Giulietti, A.M. \& Meirelles, S.T. 2007. Ilhas de vegetação em afloramentos quartzito-arenito no Morro do Pai Inácio, Chapada Diamantina, Bahia, Brasil. Acta Botanica Brasilica 2: 335-347.

De Candolle, A.P. 1828. Myrtaceae. In: Prodromus systematis naturalis regni vegetabilis 3: 207-296.

Ferreira, F.M. \& Forzza, R.C. 2009. Florística e caracterização da vegetação da Toca dos Urubus, Baependi, Minas Gerais, Brasil. Biota Neotropica 9: 131-148.

Giulietti, A.M. \& Forero, E. 1990. "Workshop" diversidade taxonômica e padrões de distribuição das angiospermas brasileiras. Introdução. Acta Botanica Brasilica 4: 3-9.

Giulietti, A.M.; Harley, R.M.; Queiroz, L.P.; Wanderley, M.G.L. \& Pirani, J.R. 2000. Caracterização e endemismos nos campos rupestres da Cadeia do Espinhaço. In: T.B. Cavalcanti \& B.M.T. Walter (eds.). Tópicos Atuais de Botânica. EMBRAPA Recursos Genéticos, Brasília. Pp. 311-318.

Giulietti, A.M.; Menezes, N.L.; Pirani, J.R.; Meguro, M. \& Wanderley, M.G.L. 1987. Flora da Serra do Cipó, Minas Gerais: caracterização e lista de espécies. Boletim de Botânica da Universidade de São Paulo 9: 1-151.

Giulietti, A.M. \& Pirani, J.R. 1988. Patterns of geographic distribution of some plant species from Espinhaço Range, Minas Gerais and Bahia, Brazil. In: Vanzolini, P.E. \& Heyer, W.R. (eds.). Proceedings of a workshop on neotropical distribution patterns. Academia Brasileira de Ciências, Rio de Janeiro. Pp. 39-69.

Govaerts, R.; Sobral, M.; Ashton, P.; Barrie, F.; Holst, B.K.; Landrum, L.R.; Matsumoto, K.; Mazine, F.F.; Nic Lughadha, E.; Proença, C.; Soares-Silva, L.H.; Wilson, P.G. \& Lucas, E. 2008. World checklist of Myrtaceae. Royal Botanic Gardens, Kew. 455p.

Guedes, M.L.S. \& Orge, M.D.R. 1998. Checklist das espécies vasculares do Morro do Pai Inácio (Palmeiras) e da Serra da Chapadinha (Lençóis), Chapada Diamantina, Bahia, Brasil. Universidade Federal da Bahia, Salvador. Pp. 1-67.

Harley, R.M. \& Simmons, N.A. 1986. Florula of Mucugê, Chapada Diamantina, Bahia, Brazil. Royal Botanic Gardens, Kew. 228p.

Harley, R.M. 1995. Introdução. In: Stannard, B.L. (ed.). Flora of Pico das Almas - Chapada Diamantina, Bahia, Brazil. Royal Botanic Gardens, Kew. Pp. 43-78.

Hatschbach, G.; Guarçoni, E.A.E.; Sartori, M.A. \& Ribas, O.S. 2006. Aspectos fisionômicos da vegetação da Serra do Cabral, Minas Gerais-Brasil. Boletim Museu Botânico Municipal, Curitiba 67: 1-33.

Kawasaki, M.L. 1989. Flora da Serra do Cipó, Minas Gerais: Myrtaceae. Boletim Botânico da Universidade de São Paulo 11: 127-170.

Landrum, L.R. \& Kawasaki, M.L. 1997. The genera of Myrtaceae in Brazil: an illustrated synoptic treatment and identification keys. Brittonia 49: 508-536.

Legrand, C.D. \& Klein, R.M. 1967. Gomidesia. (Fasc. Mirt.) In: Reitz, R. (org.). Flora ilustrada catarinense. Herbário Barbosa Rodrigues, Itajaí. Pp. 3-44.

Legrand, C.D. 1968. Las Mirtaceas del Uruguay III. Boletín de Facultad de Agronomía de Montevideo 101: 1-80.

Legrand, C.D. \& Klein, R.M. 1969. Myrcia. (Fasc. Mirt.) In: Reitz, R. (org.). Flora ilustrada catarinense. Herbário Barbosa Rodrigues, Itajaí. Pp. 219-330.

Meguro, M.; Pirani, J.R.; Giulietti, A.M. \& Mello-Silva, R. 1994. Phytophysiognomy and composition of 
the vegetation of Serra do Ambrósio, Minas Gerais, Brazil. Revista Brasileira de Botânica 17: 149-166.

Morais, P.O. \& Lombardi, J.A. 2006. A família Myrtaceae na Reserva Particular do Patrimônio Natural da Serra do Caraça, Catas Altas, Minas Gerais, Brasil. Lundiana 7: 3-32.

Mourão, A. \& Stehmann, J.R. 2007. Levantamento da flora do campo rupestre sobre canga hematítica couraçada remanescente na Mina do Brucutu, Barão de Cocais, Minas Gerais, Brasil. Rodriguésia 58: 775-786.

Munhoz, C.B.R. \& Proença, C.E.B. 1998. Composição florística do município de Alto Paraíso de Goiás na Chapada dos Veadeiros. Boletim do Herbário Ezechias Paulo Heringer 3: 102-150.

Nakajima, J.N. \& Semir, J. 2001. Asteraceae do Parque Nacional da Serra da Canastra, Minas Gerais, Brasil. Revista Brasileira de Botânica 24: 471-478.

Neri, A.V.; Meira-Neto, J.A.A.; Silva, A.F.; Martins, S.V. \& Saporetti-Júnior, A.W. 2007. Composição florística de uma área de cerrado sensu stricto no município de Senador Modestino Gonçalves, Vale do Jequitinhonha (MG) e análise de similaridade florística de algumas áreas de cerrado em Minas Gerais. Revista Árvore 31: 1109-1119.

Nic Lughadha, E. 1995. Myrtaceae. In: Stannard, B.L.; Harvey, Y.B. \& Harley, R.M. (eds.). Flora of the Pico das Almas-Chapada Diamantina, Bahia, Brazil. Royal Botanical Garden, Kew. Pp. 492-517.

Peron, M.V. 1994. O gênero Myrcia DC. coletado no município de Ouro Preto, Minas Gerais, Brasil. Daphne 4: 8-28.

Pirani, J.R.; Giulietti, A.M.; Mello-Silva, R. \& Meguro, M. 1994. Checklist and patterns of geografic distribution of the vegetation of Serra do Ambrósio, Minas Gerais, Brazil. Revista Brasileira de Botânica 17: 133-147.

Pirani, J.R., Mello-Silva, R. \& Giulietti, A.M. 2003. Flora de Grão-Mogol, Minas Gerais, Brasil. Boletim de Botânica da Universidade de São Paulo 21: 1-24.

Radford, A.E. 1986. Fundamentals of plant systematics. Harper \& Row, New York. 512p.

Ribeiro, J.F. \& Walter, B.M.T. 2008. As principais fitofisionomias do bioma Cerrado. In: Sano, S.M.; Almeida, S.P. \& Ribeiro, J.F. (eds.). Cerrado: Ecologia e Flora. Embrapa Cerrados, Brasília. Pp.151-212.

Romero, R. \& Martins, A. 2002. Melastomataceae do Parque Nacional da Serra da Canastra, Minas Gerais, Brasil. Revista Brasileira de Botânica 25: 19-24.

Romero, R. \& Nakajima, J.N. 1999. Espécies endêmicas do Parque Nacional da Serra da
Canastra, Minas Gerais. Revista Brasileira de Botânica 22: 259-265.

Romero, R. 2002. Diversidade da flora dos campos rupestres de Goiás, Sudoeste e Sul de Minas Gerais. In: Araújo, E.L.; Moura, A.N.; Sampaio, E.S.B.; Gestinari, M.S. \& Carneiro, J.M.T. (eds.). Biodiversidade, conservação e uso sustentável da Flora do Brasil. Imprensa Universitária, UFRPE, Recife. Pp. 81-86.

Sasaki, D. \& Mello-Silva, R. 2008. Levantamento florístico no cerrado de Pedregulho, SP, Brasil. Acta Botanica Brasilica 22: 187-202.

Sobral, M.; Proença, C.; Souza, M.; Mazine, F. \& Lucas, E. 2010. Myrtaceae In: Forzza, R.C. et al. (ed.). Lista de espécies da flora do Brasil. Jardim Botânico do Rio de Janeiro. Disponível em $<$ http:// floradobrasil.jbrj.gov.br/2010/FB010266>. Acesso em 10 Dez 2010.

Stannard, B.L. 1995. Flora of the Pico das Almas, Chapada Diamantina, Bahia, Brazil. Royal Botanic Gardens, Kew. 853p.

Thiers, B. [continuamente atualizado]. Index Herbariorum: a global directory of public herbaria and associated staff. New York Botanical Garden's Virtual Herbarium. Disponível em $<$ http://sweetgum. nybg.org/ih/>. Acesso em 10 Dez 2010.

Viana, P.L. \& Lombardi, J.A. 2007. Florística e caracterização dos campos rupestres na Serra da Calçada, Minas Gerais, Brasil. Rodriguesia 58: 159-177.

Vitta, F. 2002. Diversidade e Conservação da Flora nos campos rupestres da Cadeia do Espinhaço em Minas Gerais. In: Araújo, E.L.; Moura, A.N.; Sampaio, E.S.B.; Gestinari, M.S. \& Carneiro, J.M.T. (eds.). Biodiversidade, conservação e uso sustentável da Flora do Brasil. Imprensa Universitária, UFRPE, Recife. 90-94.

Werneck, M.S.; Pedralli, G.; Koenig, R. \& Giseke, L.F. 2000. Florística e estrutura de três trechos de uma floresta semidecídua na Estação Ecológica do Tripuí, Ouro Preto, MG. Revista Brasileira de Botânica 23: 97-106.

Wilson, P.G.; O’Brien, M.M.; Gadek, P.A. \& Quinn, C.J. 2001. Myrtaceae revisited: a reassessment of infrafamilial groups. American Journal of Botany 88: 2013-2025.

Zappi, D.C.; Lucas, E.; Stannard, B.L.; Lughadha, E.; Pirani, J.R.; Queiroz, L.P.; Atkins, S.; Hind, N.; Giulietti, A.M.; Harley, R.M.; Mayo, S.J. \& Carvalho, A.M. 2003. Lista de plantas vasculares de Catolés, Chapada Diamantina, Bahia, Brasil. Boletim de Botânica da Universidade de São Paulo 21: 345-398. 